\title{
Ice thickness distribution of all Swiss glaciers based on extended ground-penetrating radar data and glaciological modeling
}

\section{Article \\ *Now affiliated with Drift and Noise Polar Services $\mathrm{GmbH}$, Bremen, Germany.}

†Now affiliated with Geoprevent AG, Zurich, Switzerland.

Cite this article: Grab M et al. (2021). Ice thickness distribution of all Swiss glaciers based on extended ground-penetrating radar data and glaciological modeling. Journal of Glaciology 67(266), 1074-1092. https://doi.org/ 10.1017/jog.2021.55

Received: 10 December 2020

Revised: 23 April 2021

Accepted: 27 April 2021

First published online: 20 May 2021

\section{Key words:}

Aerogeophysical measurements; glacier volume; ground-penetrating radar; ice thickness measurements; mountain glaciers

\section{Author for correspondence:}

Melchior Grab,

E-mail: melchior@bluewin.ch

\author{
Melchior Grab ${ }^{1,2}$ (D), Enrico Mattea ${ }^{2,3}$ (D), Andreas Bauder , $^{2,4}$ (D), \\ Matthias Huss $2,3,4$ (D), Lasse Rabenstein ${ }^{1,2, *}$, Elias Hodel ${ }^{2,4}$ (D), \\ Andreas Linsbauer ${ }^{3,5}$ (D), Lisbeth Langhammer ${ }^{1}$ (D), Lino Schmid ${ }^{1,2, \dagger}$ (D), \\ Gregory Church ${ }^{1,2}$ (D), Sebastian Hellmann ${ }^{1,2}$ (D), Kevin Délèze ${ }^{6}$, Philipp Schaer 6 , \\ Patrick Lathion ${ }^{6}$, Daniel Farinotti ${ }^{2,4}$ (D) and Hansruedi Maurer ${ }^{1}$ (D)
}

${ }^{1}$ Institute of Geophysics, ETH Zurich, Zurich, Switzerland; ${ }^{2}$ Laboratory of Hydraulics, Hydrology and Glaciology (VAW), ETH Zurich, Zurich, Switzerland; ${ }^{3}$ Department of Geosciences, University of Fribourg, Fribourg, Switzerland; ${ }^{4}$ Swiss Federal Institute for Forest, Snow and Landscape Research (WSL), Birmensdorf, Switzerland; ${ }^{5}$ Department of Geography, University of Zurich, Zurich, Switzerland and ${ }^{6}$ Geosat SA, Sion, Switzerland

\begin{abstract}
Accurate knowledge of the ice thickness distribution and glacier bed topography is essential for predicting dynamic glacier changes and the future developments of downstream hydrology, which are impacting the energy sector, tourism industry and natural hazard management. Using AIR-ETH, a new helicopter-borne ground-penetrating radar (GPR) platform, we measured the ice thickness of all large and most medium-sized glaciers in the Swiss Alps during the years 2016-20. Most of these had either never or only partially been surveyed before. With this new dataset, 251 glaciers - making up $81 \%$ of the glacierized area - are now covered by GPR surveys. For obtaining a comprehensive estimate of the overall glacier ice volume, ice thickness distribution and glacier bed topography, we combined this large amount of data with two independent modeling algorithms. This resulted in new maps of the glacier bed topography with unprecedented accuracy. The total glacier volume in the Swiss Alps was determined to be $58.7 \pm 2.5 \mathrm{~km}^{3}$ in the year 2016. By projecting these results based on mass-balance data, we estimated a total ice volume of $52.9 \pm 2.7 \mathrm{~km}^{3}$ for the year 2020 . Data and modeling results are accessible in the form of the SwissGlacierThickness-R2020 data package.
\end{abstract}

\section{Introduction}

Since the end of Little Ice Age around 1850, more than half of the glacier volume in the Swiss Alps has been lost, with increasing rates in the recent decades (Zemp and others, 2015). Projections of future glacier change imply that under high-emission scenarios, the Alps will be largely deglacierized by 2100 (Zekollari and others, 2019). This will lead to remarkable changes in the annual regime of river runoff (Braun and others, 2000; Milner and others, 2009; Huss, 2011). Since glaciers act as a water reservoir at diverse timescales (Beniston and others, 2018), they are important, for example for electricity production from hydropower (Beniston, 2012; Finger and others, 2012; Gaudard and others, 2016), which is relevant for Switzerland as hydropower contributes with around $55 \%$ to the total annual electricity production (BFE, 2019). Glaciers are also of high societal relevance in many other fields, such as agriculture (Fink and others, 2004; Beniston, 2012), natural hazards (Huggel and others, 2004; Haeberli, 2005), tourism (Fischer and others, 2011; Beniston, 2012), supply of drinking water (Wyer, 2008) or with regard to sea level rise (Zemp and others, 2015). On the contrary, new chances might arise, for example for the electricity production from hydropower, due to new lakes forming in deglacierizing regions (Haeberli and others, 2016; Farinotti and others, 2019), where potentially new storage power plants can be installed (Ehrbar and others, 2018).

Accurate knowledge about today's ice volume and the subglacial topography is key to calculate future changes in river runoff regimes (e.g. Gabbi and others, 2012; Gaudard, 2015) or predicting the occurrence of alpine lakes forming after glaciers have retreated (Linsbauer and others, 2012; Haeberli and others, 2016). At spatial scales beyond those of individual glaciers, this information is typically obtained from ice thickness models or scaling approaches (Bahr and others, 2015; Farinotti and others, 2017). Various ice thickness models have recently been developed which allow estimating the ice thickness distribution from the glacier surface topography, glacier outlines and sometimes auxiliary data such as mass-balance estimates, ice flow velocities or branch lines. Currently applied models were, for example, presented by Farinotti and others (2009b, extended later to the global scale by Huss and Farinotti, 2012), Morlighem and others (2011), Paul and Linsbauer (2012), Clarke and others (2013), Brinkerhoff and others (2016) and Rabatel and others (2018). Based on such models, ice thickness and volume estimates specifically for Switzerland were presented by Farinotti and others (2009a), Linsbauer and others (2012) and Fischer and others (2015), whereas additional independent 
regional estimates at the scale of the European Alps are available from Haeberli and Hölzle (1995) and Farinotti and others (2019).

Ice thickness estimates obtained from modeling exhibit substantial uncertainties unless they are calibrated to ground-truth data (Farinotti and others, 2021). For the Antarctic and Greenlandic ice sheets, measured ice thickness data have been acquired systematically with a comprehensive coverage (e.g. Dowdeswell and Evans, 2004; Allen and others, 2010), enabling to interpolate the ice thickness distribution in these regions more accurately (e.g. Huss and Farinotti, 2014; Morlighem and others, 2020). Andreassen and others (2015) used measured ice thickness for 32\% of the glacier area of mainland Norway, and Helfricht and others (2019) relied on direct thickness observations for $46 \%$ of Austria's glacierized areas to obtain complete ice thickness maps in combination with calibrated ice thickness models. A similar study has been accomplished by Pelto and others (2020) for the Canadian part of the Columbia River Basin. For other regions, available ice thickness observations are usually too sparse and models of entire mountain ranges are only calibrated for a few glaciers and the calibration factors are then projected to all other glaciers (Farinotti and others, 2009a; Linsbauer and others, 2012; Werder and others, 2020). To improve ice volume estimates and to obtain the subglacial topography with higher accuracy, it is therefore substantial to provide more direct measurements of the glacier thickness as for instance concluded by Farinotti and others (2017).

Apart from drilling boreholes to the bedrock, which is only feasible in limited numbers, radar sounding has been established as the most common technique to measure the ice thickness of glaciers (Plewes and Hubbard, 2001; Woodward and Burke, 2007). This is true for both, environments with non-temperate ice, such as in Antarctica or Greenland (e.g. Bingham and Siegert, 2007), as well as in regions with temperate glaciers such as in Alaska, Patagonia, the Himalaya or in the European Alps (e.g. Blindow and others, 2012). For surveying temperate glaciers with radar, a major challenge arises from the substantially higher dampening of electromagnetic waves in comparison with cold ice (Watts and England, 1976). For this reason, impulse radar systems have been employed, hereafter referred to as ground-penetrating radars (GPR). They are able to transmit $\sim 1$ cycle at high voltages and with a relatively low central frequency defined by the antenna length (Plewes and Hubbard, 2001). Typically, their frequencies range from a few megahertz, depending on the maximum manageable antenna length, up to several tens of megahertz, depending on the required maximum penetration depth.

Airborne GPR systems with sufficiently low frequency to penetrate temperate glaciers have been used worldwide since decades (Watts and Wright, 1981; Kennett and others, 1993; Christensen and others, 2000; Conway and others, 2009; Blindow and others, 2011; Rignot and others, 2013; Gacitúa and others, 2015; Urbini and others, 2017; Langhammer and others, 2019b; Pritchard and others, 2020), carried either by fixed-wing airplanes on wide and flat glaciers and ice caps or by helicopters on glaciers in narrow valleys or high-altitude environments with steep glaciers. Also in the Swiss Alps, several helicopter-borne GPR systems have been employed during the last two decades as summarized by Rutishauser and others (2016). Together with a number of groundbased surveys (e.g. Bauder and others, 2003; Huss and Fischer, 2016; Feiger and others, 2018), they contribute largely to the ice thickness datasets for this region, and are available through the public glacier ice thickness database GlaThiDa (Gärtner-Roer and others, 2014; Welty and others, 2020). To complement this pre-existing database, we have established the new helicopterborne GPR platform AIR-ETH (Langhammer and others, 2019b). It is the first GPR platform with two orthogonal antenna pairs, which significantly improves the bedrock recovery of valley glaciers (Langhammer and others, 2017).
Our study has three objectives: first, we present a large amount of new ice thickness data from Swiss glaciers, acquired using the AIR-ETH system. These data substantially extend the already existing database of ice thickness point measurements. Second, we generate continuous maps of the ice thickness distribution through interpolation by glaciological modeling based on the extended and highly comprehensive set of ice thickness data. For that purpose, we apply two different algorithms, namely the recently developed Glacier Thickness Estimate (GlaTE) algorithm (Langhammer and others, 2019a) and the Ice Thickness and Volume Estimation method Observation-based (ITVEO) that is based on the concepts of Huss and Farinotti (2012). Additionally, we use the ice thickness distributions and the corresponding GPR data to calibrate the models for estimating the ice thickness distribution of the remaining, mostly small glaciers for which still no GPR data exist. This is the first time that at the regional scale, ice thickness distribution and glacier bed topography has been determined based on such a high density of direct ice thickness observations. The third and final aim of our study is to provide a new estimate of the total ice volume in the Swiss Alps.

\section{Study region and datasets}

A glacier inventory is a prerequisite for a regional assessment of ice thickness distribution and glacier volume. Here, we refer to the Swiss Glacier Inventory 2016 (SGI2016, GLAMOS, 2020b; Linsbauer and others, subm.) for the definition of glacierized areas. This inventory comprises 1400 glaciers with a total area of $961 \mathrm{~km}^{2}$ and refers to the years between 2013 and 2018, with a center date in 2016. A number of 160 of these glaciers are larger than $1 \mathrm{~km}^{2}$ and cover a total area of $767 \mathrm{~km}^{2}$, whereas the overwhelming majority of the glaciers are small and, thus, contribute little to the total ice volume (e.g. Fischer and others, 2014). Most glaciers are located in the Bernese and Valais Alps, where the Alps reach the highest elevation within our study region. Substantial glacierized areas also exist in the central and eastern Swiss Alps. The outlines provided by the SGI2016 define the lateral extent of our glacier maps. Additionally, the SGI2016 provides raster data indicating which parts of the glaciers are covered by supraglacial debris (GLAMOS, 2020b).

Our study region is covered by swissALTI3D, a recent, highquality digital elevation model (DEM) provided by the Federal Office of Topography (Swisstopo, 2010). It is accompanied by well-documented meta data. The DEM used for modeling is the 2019-release of the swissALTI3D with $2 \mathrm{~m}$-resolution (Swisstopo, 2019), which we down-sampled to a resolution of 10 $\mathrm{m}$. The acquisition year over the extent of all glaciers can be retrieved from the meta data, which is provided within cells of $1 \mathrm{~km} \times 1 \mathrm{~km}$. It provides the mode (most occurring) year, as well as the youngest and oldest recording years of the base data used for producing the DEM (Weidmann and others, 2018). On average, the 2019-release of swissALTI3D represents the surface topography of the year 2015, with oldest being from 2007 and youngest from 2017.

To date, a large amount of ice thickness data for Swiss glaciers has been acquired with GPR by various researchers. Most of them are available through GlaThiDa (GlaThiDa Consortium, 2019) operated by the World Glacier Monitoring Service (GärtnerRoer and others, 2014; Welty and others, 2020). In addition to these data, we also use the ice thickness data measured with seismic methods by Thyssen and Ahmad (1969), covering an area of Konkordiaplatz where the three main branches of Aletschgletscher merge. At this location, the largest ice thickness in the Swiss Alps occur, but to date the glacier bed underneath the deepest ice has not been detected with GPR. The overdeepening detected by Thyssen and Ahmad (1969) was later confirmed by drilling boreholes as described in the study of Hock and others (1999). 
In total, the data published through GlaThiDa comprise around $950 \mathrm{~km}$ of GPR profiles, mostly acquired on the larger glaciers in the Bernese and Valais Alps. Additionally, the Glaciology Group at the Laboratory of Hydraulics, Hydrology and Glaciology (VAW, ETH Zurich) archived another $\sim 550 \mathrm{~km}$ of GPR profiles, which were measured by various researchers but not published so far. References of the corresponding studies are listed in Table 2. The ice thickness data were complemented with another $950 \mathrm{~km}$ of profiles, recorded in the framework of this study as introduced below. They were recorded not only in the Western Swiss Alps, where most of the previous surveys were conducted, but also on the glaciers in the central and eastern Swiss Alps, for which almost no data existed before. An overview of which glaciers have been surveyed to date is shown in Figure 1a. In Figure 1b, the location of GPR sections is shown for the Bernese Alps. For analogous figures for other regions, refer to the Supplementary material.

Since ice thicknesses were measured in various years and seasons, ice thicknesses used as input for the ice thickness distribution modeling were standardized by subtracting the measured glacier bed from the DEM. This requires the elevation datum of measured glacier surface- and glacier bed-elevation to be consistent with the datum of the DEM. Therefore, we compared the surface elevation accompanying the GPR datasets with a DEM dating back as close as possible to the time of GPR-data acquisition. In case the two surface elevations differed strongly, which occurred when surface elevations were not measured simultaneously during GPR acquisition, directly the measured ice thickness was used as input for the ice thickness interpolation. This results in increased uncertainties for the interpolated ice thickness, which was taken into account as detailed in Appendixes $\mathrm{C}$ and D. This was the case for about a dozen small glaciers surveyed between 2009 and 2015 (see metadata of SwissGlacierThickness-R2020, Grab and others, 2020).

\section{Methods}

\subsection{GPR surveying}

\subsubsection{GPR data acquisition}

GPR data were acquired in the winter and spring seasons of the years 2016-20 with the GPR platform AIR-ETH (Langhammer and others, 2019b). This GPR platform consists of the pulseEkko radar system from Sensors \& Software and is carried by a helicopter as a sling-load. For the campaigns presented here, it was equipped with two orthogonal transmitter-receiver antenna pairs of $25 \mathrm{MHz}$ center frequency, in order to record dual-polarization data. Both pairs were mounted in broadside configuration and were recording alternatingly around eight traces per second each. With the target flight speed of $37 \mathrm{~km} \mathrm{~h}^{-1}$ (20 knots), this resulted in a trace every $0.8 \mathrm{~m}$ available for the consequent data processing. From three global navigation satellite system (GNSS) antennas, the pitch, roll and yaw of the platform was obtained, whereas a laser-altimeter constantly logged the distance to the glacier surface. From this information, the glacier surface elevation underneath the platform was deduced. The recording and processing of the differential GNSS and laser altimeter-data, as well as the navigation aid for the pilot, was performed by GEOSAT SA, a Swiss-based surveying company. The target height of the antennas above ground was defined as $30 \mathrm{~m}$, which in field-implementation typically varied by around $\pm 20 \mathrm{~m}$. Larger heights were avoided for data-quality reasons and lower heights for safety reasons.

For typical valley glaciers, one longitudinal (i.e. along the glacier flow direction) and several cross-profiles, around every $250 \mathrm{~m}$ (small glaciers) and up to every $750 \mathrm{~m}$ (larger glaciers), were recorded. For more complex-shaped glaciers, this configuration was adapted with a similar profile density, seeking roughly orthogonal intersections. This facilitated the discrimination of off-plane reflections and reflections from steep valley walls by comparing orthogonal profiles during data interpretation. Profile locations (interpreted parts) are shown for an example region in Figure 1b. The ultimate goal of our campaigns was to cover as many glaciers as possible with the given finances. Therefore, data acquisition missions were conducted regionwise and it was aimed to cover possibly all glaciers in each region, unless they were geographically very isolated and/or very small.

\subsubsection{GPR data processing}

A data-processing workflow was established based on the experience of previous studies with helicopter-borne GPR (Merz and others, 2015; Rutishauser and others, 2016; Grab and others, 2018; Langhammer and others, 2019b). It mainly consists of standard GPR-processing steps that are also commonly used for processing ground-based data. A crucial adaption, however, is required because data from helicopter-borne GPR are contaminated with severe ringing noise (Fig. 2a) due to the interference of the electromagnetic waves with the helicopter (Rutishauser and others, 2016; Langhammer and others, 2019b). All processing steps were implemented in our in-house processing package GPRglaz (e.g. Grab and others, 2018), which is based on Matlab and uses parts of the CREWES library (e.g. Margrave and Lamoureux, 2019).

Data from an example GPR-profile are shown in Figure 2 after selected processing steps. It has been recorded in February 2019 and its location is marked as Profile 7 in Figure 1b. The main processing steps are (1) a time zero correction based on the arrival of the direct wave, (2) removal of the ringing noise using an optimized procedure of singular value decomposition filtering as described in detail by Grab and others (2018), (3) bandpass filtering, (4) merging of the dual-polarization data channels as described in detail by Langhammer and others (2019b), (5) trace binning for a regular sampling at a spatial sampling rate depending on the flight speed and (6) image focusing and time-to-depth conversion by migrating the data with constant radar wave velocities for ice and air of 0.169 $\mathrm{m} \mathrm{ns}^{-1}$ (Glen and Paren, 1975) and $0.299 \mathrm{~m} \mathrm{~ns}^{-1}$, respectively. For the migration, a Kirchhoff time migration scheme (after Margrave and Lamoureux, 2019) was used which yielded satisfactory results after relatively short computation times, but for some profiles also a computationally more expensive reverse time migration was considered (Grab and others, 2018). The identical processing flow was applied to data from both channels of the dual polarization AIR-ETH system. Additionally, the data of the two channels were merged by summation, and the processing was applied to the resulting trace as well. Therefore, three images were available for the interpretation: one from records with the antennas orthogonal to flight direction (channel 1), one from records with the antennas parallel to flight direction (channel 2) and one for the merged channels.

\subsubsection{Interpretation of glacier bed reflections}

For many profiles, images from the merged channels show substantial improvements in quality (see Langhammer and others, $2019 b$, for more details). In some cases, it turned out to be useful to additionally consider the individual channels during data interpretation. In a number of profiles the glacier bed reflection was only visible in the data of one channel, thereby confirming the usefulness of the dual-polarization AIR-ETH system. Another advantage of the dual-polarization data is that unwanted events in the data, such as reflections from steep valley walls, were often only visible in one channel. An example is shown in Figures $3 \mathrm{a}, \mathrm{b}$, where some reflections with a linear move-out and slightly elevated frequency content, typical for reflections from valley walls, only occurs in the image recorded with channel 1 . Such events may interfere with the glacier bed reflection and hinder the interpretation. 


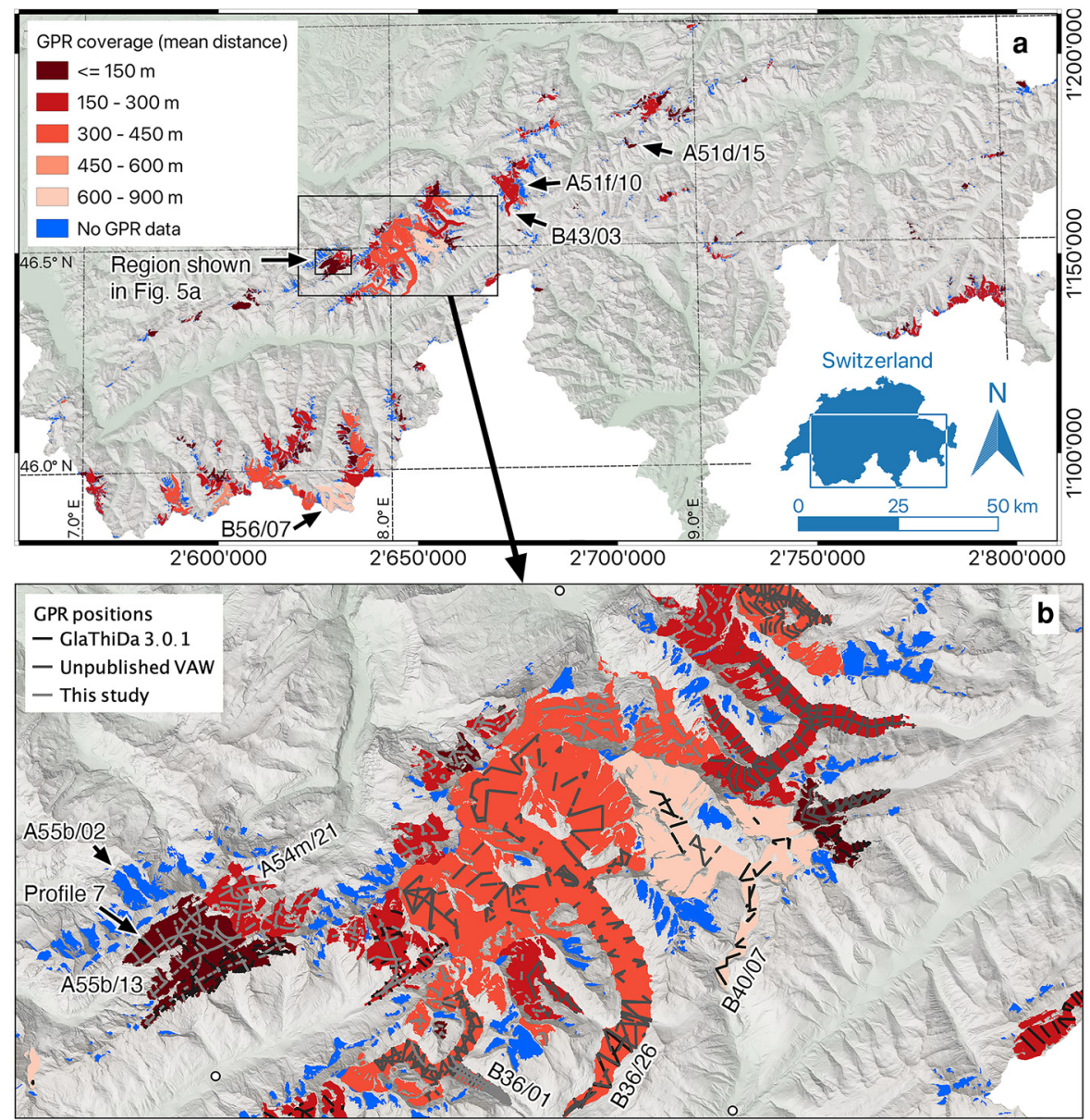

Fig. 1. Overview of GPR coverage: (a) SGI2016 outlines of all glaciers in the Swiss Alps. Glaciers for which no GPR data have been acquired to date are in blue. Glaciers for which GPR data are available are shown in red, with the color-code indicating the density of the data coverage expressed by the mean of the distances of all points on the glacier to the closest GPR-measurement point. (b) Zoom into the Bernese Alps with the location of the GPR-measurement points shown in light gray to black depending on the data source. See the Supplementary material for other parts of the Swiss Alps. Background: hillshade from the swissALTI3D after Swisstopo (2019).
When interpreting glacier bed reflections, we distinguished three quality classes (Fig. 3c) in order to later account for the data quality when estimating the uncertainty in the measured ice thickness and to deal with ambiguous reflections. The first and highest quality class was assigned to coherent reflections with a clear onset. The second class was assigned for reflections not occurring coherently over greater distances or with a poorly defined onset. In either case, an alternative event could be selected, for example if it was not possible to clearly distinguish between a true glacier bed reflection occurring from within the profile and an image of an off-plane reflection. The hierarchy of main and alternative reflection was defined on a case-by-case basis, either by the coherence of the reflection or from a glaciological point of view. In cases of multiple reflections, for which no clear onset can be identified, but which most probably originate from the glacier bed, it was not possible to pick an individual event. Instead, a minimum-maximum time window was picked and labeled as third-class pick, whereas the actual ice thickness was defined by the mean of the selected range.

In case of an unambiguous interpretation of glacier bed reflections, the uncertainty in measured ice thickness was estimated from the error in the GPR wave velocity in temperate ice and the uncertainty in picking reflections in the radargrams. For the GPR wave velocity we used $0.169 \pm 0.005 \mathrm{~m} \mathrm{~ns}^{-1}$ following Glen and Paren (1975), which is less conservative than the uncertainty of $\pm 0.008 \mathrm{~m} \mathrm{~ns}^{-1}$ used by Lapazaran and others (2016) as that study applied it to a polythermal glacier. For the picking uncertainty, Rutishauser and others (2016) estimated an uncertainty of $\pm 5 \mathrm{~m}$. From our experience, this picking uncertainty is an appropriate estimate on average. Here, we used $\pm 3 \mathrm{~m}$ for reflections with a well-defined onset (class 1 ) and $\pm 7 \mathrm{~m}$ for reflections with a poorly defined onset (classes 2 and 3 ). For data from the literature or from older studies, for which we do not know the data quality, an average picking uncertainty of $\pm 5 \mathrm{~m}$ was assumed. In cases, where the interpretation was ambiguous and an alternative reflection was identified or reflections were picked over a time window (class 3), the uncertainty bound spans over the entire range of the identified glacier bed reflections, additionally to the velocity and the picking uncertainty. This procedure results in uncertainty ranges $\Delta h_{\mathrm{GPR}}^{-}$toward smaller and $\Delta h_{\mathrm{GPR}}^{+}$toward larger ice thickness as displayed in Figure $3 \mathrm{~d}$.

Since the GPR data were acquired in different years and during different seasons, the measured ice thicknesses were not directly compatible with the DEM on which the ice thickness interpolation was based on. Thanks to the differential GNSS and laseraltimeter measurements with the AIR-ETH system, however, the precise elevation datum of the glacier surface and likewise of the glacier bed is known for each measured ice thickness. It was therefore permissible to subtract the glacier bed elevation from the DEM (SwissALTI3D-r2019) and use this standardized ice thickness $h_{\mathrm{GPR}}$ (see Fig. 3d) as input for the ice thickness interpolation as explained in Section 2.

\subsection{Interpolation with ice thickness modeling}

To obtain continuous ice thickness maps from the partly sparse coverage of GPR profiles, we applied an interpolation using two independent distributed ice thickness modeling algorithms. The basic concept is to optimize an ice thickness model using the available data for each glacier and to use the calibrated model to optimally estimate ice thickness distributions in unmeasured regions of the glacier. To this end, we rely on the algorithm Glacier Thickness Estimate (GlaTE) that has been recently developed by Langhammer and others (2019a), and on the Ice 

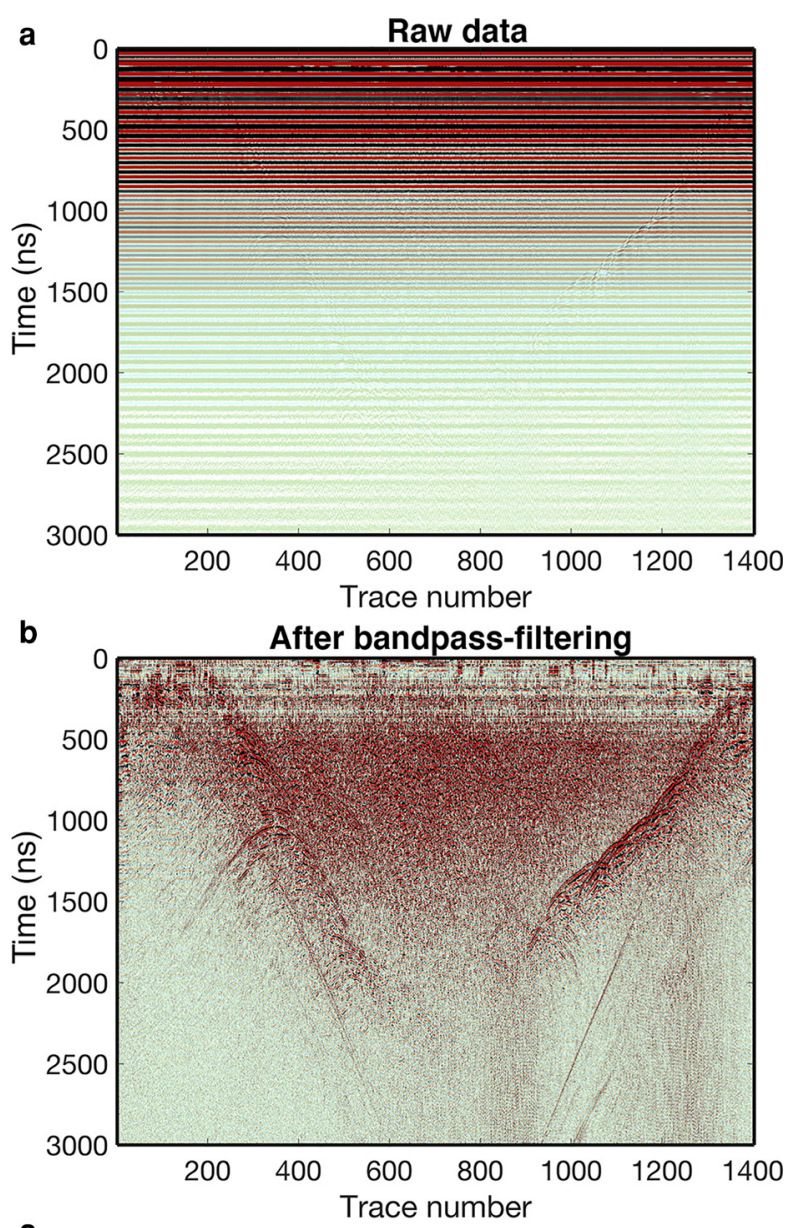

c After migration \& time/depth conversion

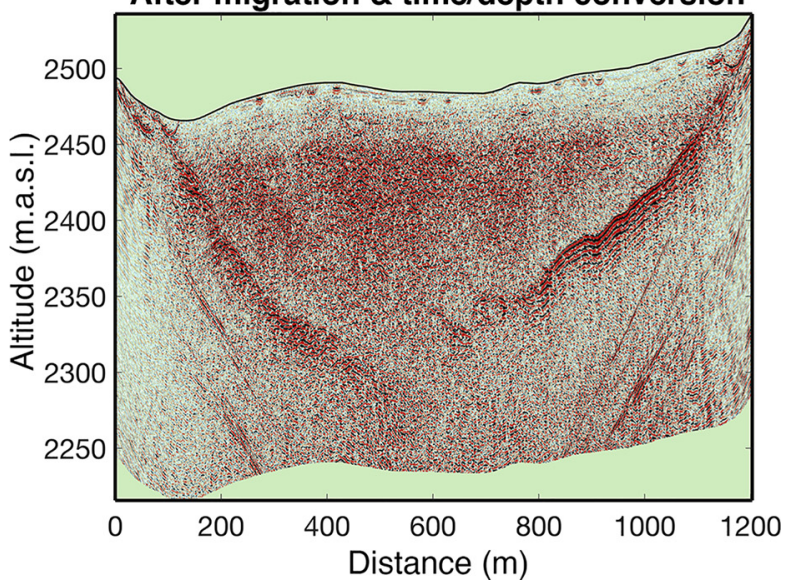

Fig. 2. Selected data-processing steps for profile 7 recorded on Kanderfirn (A55b/13 in Fig. 1b) in February 2019: (a) rawdata, (b) data after ringing removal and bandpass filtering and (c) data after focusing and time-to-depth conversion using Kirchhoff migration.

Thickness and Volume Estimation method Observation-based (ITVEO) method, a further development of the approach presented in Huss and Farinotti (2012).

GlaTE and ITVEO are well suited for the current study, because they can efficiently account for large amounts of ice thickness measurement data and are relatively inexpensive for applications to large sets of glaciers. Both models follow a concept presented first by Farinotti and others (2009b), which bases on mass conservation, apparent mass balances and Glen's ice flow law (Glen, 1955). A main difference persists in the way this concept is implemented, especially with computations being performed within ice flow sheds for GlaTE and within elevation bands for ITVEO. Furthermore, the schemes with which ice thickness observations are incorporated are also fundamentally different among the two models as explained in detail below.

The final maps of ice thickness distribution and glacier bed topography were obtained in a last step by averaging the results of the two algorithms, and is subsequently referred to as the MEAN. Unless specified differently, we hereafter refer to the MEAN result when discussing ice thickness distributions and glacier bed topography maps.

\subsubsection{Glacier thickness estimate (GlaTE)}

The GlaTE algorithm used in this study is identical to the one presented in Langhammer and others (2019a), except for a few modifications. GlaTE includes a modeling algorithm equivalent to the one of Clarke and others (2013). The approach builds on a physically based ice flow model that estimates the glacier bed topography from the surface topography, apparent mass-balance fields, and a stress-strain relationship for basal shear derived from Glen's law (Glen, 1955). The resulting ice thickness model is combined with the ice thicknesses measured with GPR using an inversion scheme. As detailed in Appendix A, this scheme is an extended form of the one presented by Langhammer and others (2019a), with the main difference that it also accounts for glacier bed topography gradients along the glacier boundary.

\subsubsection{Ice thickness and volume estimation - observation-based (ITVEO)}

The basis of the ITVEO approach for inter- and extrapolating point ice thickness observations to the entire glacier is an ice thickness model that was originally developed for global-scale applications by Huss and Farinotti (2012). In the framework of ITMIX2 (Farinotti and others, 2021) the approach has been extended to be able to incorporate thickness observations for constraining the model solution to match measurements. This methodology has been further developed in the current study as described in Appendix B.

\subsubsection{Final ice thickness distribution and glacier bed topography} The two independent models GlaTE and ITVEO result in ice thickness distributions $h_{\text {glate }}(x, y)$ and $h_{\text {itveo }}(x, y)$. Since both were computed within identical glacier outlines and produced on identical grids with a $10 \mathrm{~m}$ resolution, no further processing was required prior to averaging the two models. With the above notation, the final maps of ice thickness distributions and glacier bed topography is simply obtained from

$$
h(x, y)=\frac{h_{\text {glate }}(x, y)+h_{\text {itveo }}(x, y)}{2},
$$

to which we refer to hereafter as MEAN. It has been concluded from the Ice Thickness Model Intercomparison eXperiments ITMIX (Farinotti and others, 2017) and ITMIX2 (Farinotti and others, 2021), that model ensembles have a higher skill in predicting ice thickness than any individual model, provided all models perform similarly well. In ITMIX2, GlaTE and ITVEO both showed a similarly good performance. Thus, averaging these two models is a first step toward a more robust areal interpolation.

The measured ice thicknesses used as input for obtaining the ice thickness distributions were standardized to be compatible with the DEM as introduced in Section 2. Therefore, DEM, ice thickness distribution and glacier bed topography form a consistent triplet. This permits the glacier bed topography to be determined by subtracting the ice thickness from the DEM. The glacier bed topography is thus consistent with the DEM and, by combining the two, terrain models of the hypothetically completely deglacierized landscape can be generated. 

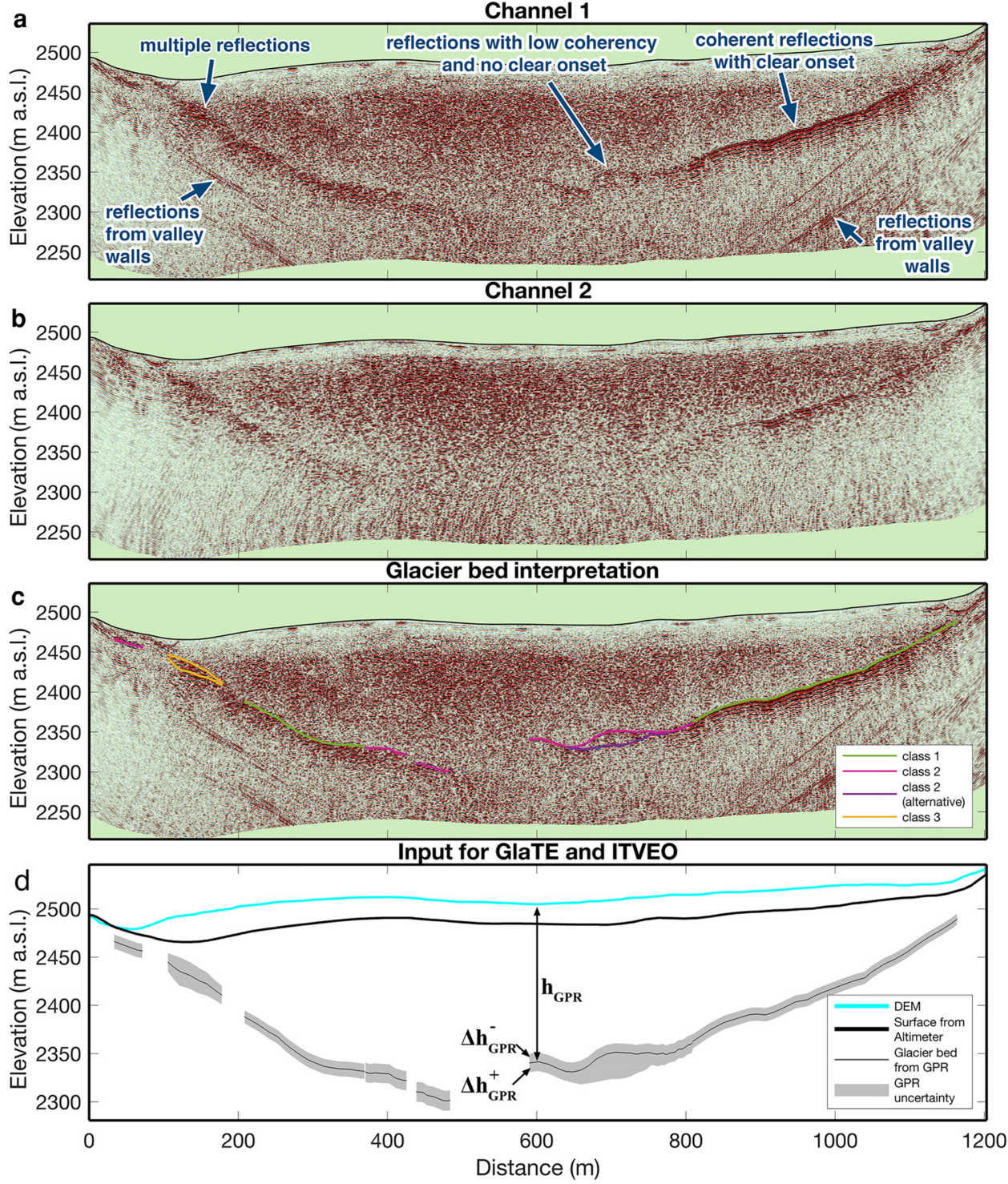

Fig. 3. Glacier bed interpretation of profile 7 from Kanderfirn (A55b/13): migrated reflection image recorded with (a) channel 1 and (b) channel 2, (c) glacier bed interpretation and classes depending on reflection quality and (d) corresponding ice thickness and uncertainty ranges used as input for GlaTE and ITVEO.

\subsection{Ice volumes, homogenization to a specific year and temporal extrapolation}

The ice volume of individual glaciers was obtained from summation of interpolated thicknesses at all gridcells, multiplied with the cell area $10 \mathrm{~m} \times 10 \mathrm{~m}$. The resulting ice volumes refer to the recording years of the base data on which the glacier outlines and the surface topography given by the DEM are based on, hereafter referred to as the inventory year. In order to provide a nation-wide ice volume estimate referring to a specific year, a temporal homogenization of the glacier-specific volume to a single year was required. The center year of the 2019-release of swissALTI3D is 2015 (slightly younger according to the areaweighted average), whereas it is 2016 for the SGI2016 (GLAMOS, 2020b). We thus decided to homogenize the volume to the year 2016, referred to as the reference year hereafter.

For this homogenization we rely on both long-term geodetic ice volume changes available for each individual Swiss glacier over the period 1980-2010 (Fischer and others, 2015), and in situ observations of year-to-year mass-balance variability at up to 20 glaciers in all glacierized regions of Switzerland spanning the period 1970-2020 (GLAMOS, 1881-2018, 2019). For each glacier with direct observations, the annual mass-balance anomaly with respect to that glacier's long-term mean, given by Fischer and others (2015), was evaluated and spatially extrapolated to all unmeasured Swiss glaciers based on an inverse-distance weighting scheme. For extrapolation to glaciers North of the main Alpine crest this scheme attributes a higher weight to observed mass balances on the same side of the weather divide, and vice versa for glaciers south of the main Alpine crest. Annual mass-balance anomalies $\Delta B_{i, y}$ of glacier $i$ and year $y$ were then superimposed on the glacier's long-term average mass balance $\bar{B}_{i}$. Converting glacier mass balance into an annual change in ice volume requires an estimate of the time-evolving area $A_{y}$ for each glacier and a mean density $\rho_{\Delta V}=850 \mathrm{~kg} \mathrm{~m}^{-3}$ (Huss, 2013) for the occurring volume change. Mean annual glacier-specific area-change was derived from the observed glacier area change between 1973 and 2010 (Fischer and others, 2014). The same rate was also used to extrapolate glacier area up to 2020. Ice volume change $\Delta V_{g, y}$ of glacier $i$ in year $y$ is thus obtained as

$$
\Delta V_{i, y}=\left(\Delta B_{i, y}+\overline{B_{i}}\right) \cdot A_{i, y} \cdot \frac{\rho_{\text {water }}}{\rho_{\Delta \mathrm{V}}} .
$$


Summation of annual ice volume changes relative to ice volume for the inventory year, that is the volume based on direct thickness observations, yields series for the evolution of each glacier's volume over time. Overall, ice volume in Switzerland is finally obtained for every year between 1970 and 2020 as the total volume of all glaciers. This series is useful to relate our new regional ice volume estimate to previous studies, and to analyze relative changes in ice volume.

\section{Uncertainties}

\subsection{Point-specific ice thickness uncertainty}

The point-specific ice thickness uncertainty is estimated as the standard uncertainty $u^{ \pm}(x, y)$ in ice thickness at an arbitrary point of the resulting ice thickness models. For its estimation, we consider uncertainties of the ice thickness interpolation $u_{\mathrm{int}}^{ \pm}(x, y)$, uncertainties in GPR measurements $u_{\mathrm{gpr}}^{ \pm}(x, y)$ and uncertainties in surface elevation $u_{\text {surf }}^{ \pm}(x, y)$. The superscript ' + ' indicates uncertainty toward larger and the superscript '-' toward smaller ice thickness, respectively. Quantity $u_{\text {int }}^{ \pm}(x, y)$ was estimated using a bootstrap technique (Efron, 1979), $u_{\mathrm{gpr}}^{ \pm}(x, y)$ by repeating the ice thickness interpolation while replacing the measured ice thickness input $h_{\mathrm{GPR}}$ by $h_{\mathrm{GPR}}-\Delta h_{\mathrm{GPR}}^{-}$and $h_{\mathrm{GPR}}+\Delta h_{\mathrm{GPR}}^{+}$, and for $u_{\text {surf }}^{ \pm}(x, y)$ we estimated a value which is constant across individual glaciers. More details about the computation of these uncertainty components are given in Appendix C.

Since quantities $u_{\mathrm{int}}^{ \pm}(x, y), u_{\mathrm{gpr}}^{ \pm}(x, y)$ and $u_{\text {surf }}^{ \pm}(x, y)$ are controlled by mechanisms independent from each other, they are presumed to be uncorrelated. The total ice thickness uncertainty at a specific point is therefore obtained from

$$
u^{ \pm}(x, y)=\sqrt{u_{\mathrm{int}}^{ \pm}(x, y)^{2}+u_{\mathrm{gpr}}^{ \pm}(x, y)^{2}+u_{\mathrm{surf}}^{ \pm}(x, y)^{2}},
$$

which is applied separately for quantities $u^{+}$and $u^{-}$.

\subsection{Ice volume uncertainty}

The ice volume uncertainty $\bar{u}_{V}$ is expected to be substantially smaller than the sum of the point-specific ice thickness uncertainties $u^{ \pm}(x, y)$ introduced above, because values of $u^{ \pm}(x, y)$ cancel each other out to a certain extent when averaging over entire glaciers and, even more, over the entire Swiss Alps. Since uncertainties in total glacier volumes can be regarded as mean uncertainties, we use the overline-notation to distinguish the volumetric uncertainty components from their point-specific counterparts. The components incorporated for computing $\bar{u}_{\mathrm{V}}$ are the uncertainties in ice thickness interpolation $\bar{u}_{\text {int }}$, uncertainties due to GPR measurement errors $\bar{u}_{\text {gpr }}$, uncertainties in glacier area $\bar{u}_{\text {area }}$ and uncertainties due to errors in surface elevation $\bar{u}_{\text {surf }}$. The GPR measurement errors affect the ice volume uncertainty of glaciers both with and without GPR data, the latter via the model calibration. To distinguish between the two cases, we define $\bar{u}_{\text {gpr }}=\bar{u}_{\mathrm{w} / \text { gpr }}$ for glaciers with GPR data, and $\bar{u}_{\mathrm{gpr}}=\bar{u}_{\mathrm{w} / \mathrm{ogpr}}$ for glaciers without GPR data.

The computation of the ice volumes consists of the summation over all cells and all glaciers. When propagating the errors, we have to consider that uncertainties of individual cells are usually correlated and, for some uncertainty components, a correlation among all glaciers has to be considered as well. Details about the computation of these uncertainty components are given in Appendix D.

For propagating the individual uncertainty components to the total volume uncertainty $\bar{u}_{\mathrm{V}, i}$ of an individual glacier $i$, all
Table 1. GPR contribution from the different sources and how many glaciers (in numbers, area and volume) are covered

\begin{tabular}{lcccc}
\hline Source & $\begin{array}{c}\text { Profile length } \\
\mathrm{km}\end{array}$ & $\begin{array}{c}\text { Number of } \\
\text { glaciers }\end{array}$ & $\begin{array}{c}\text { Glacier area } \\
\mathrm{km}^{2}\end{array}$ & $\begin{array}{c}\text { Glacier volume } \\
\mathrm{km}^{3}\end{array}$ \\
\hline GlaThiDa & 950 & 76 & 471 & 39 \\
VAW & 550 & 28 & 352 & 33 \\
New (2016-19) & 890 & 168 & 393 & 21 \\
New (2020) & 60 & 33 & 48 & 2 \\
Total & 2450 & 251 & 782 & 54 \\
Fraction & & $19 \%$ & $81 \%$ & $93 \%$ \\
\hline
\end{tabular}

'For sources 'GlaThiDa' (3.0.1) and 'VAW' (unpublished), see Section 2. 'New' refers to the data recorded in this study. Data from 'GlaThiDa', 'VAW', 'New (2016-19)' were used as input for the glaciological modeling, whereas data 'New (2020)' were recorded in spring 2020 and used for independent validation only. 'Total' is the sum of numbers from all sources (a specific glacier can be covered with data from different sources), and 'Fraction' is the percentage from the Swiss-total.

components are again presumed to be uncorrelated, leading to an uncertainty of

$$
\bar{u}_{\mathrm{V}, i}=\sqrt{\bar{u}_{\mathrm{int}, i}^{2}+\bar{u}_{\mathrm{gpr}, i}^{2}+\bar{u}_{\mathrm{area}, i}^{2}+\bar{u}_{\mathrm{surf}, i}^{2}} .
$$

Across the entire Swiss Alps, it is assumed that $\bar{u}_{\text {int }, i}$ and $\bar{u}_{\mathrm{gpr}, i}$ are uncorrelated among different glaciers, whereas a correlation is assumed for $\bar{u}_{\text {area }, i}$ and $\bar{u}_{\text {surf }, i}$ (see Appendix D for further details). From the corresponding Swiss-wide values for these uncertainty components, the uncertainty of the entire ice volume in the Swiss Alps is estimated to be

$$
\bar{u}_{\mathrm{V}}=\sqrt{\bar{u}_{\mathrm{int}}^{2}+\bar{u}_{\mathrm{gpr}}^{2}+\bar{u}_{\mathrm{area}}^{2}+\bar{u}_{\mathrm{surf}}^{2}} .
$$

Quantity $\bar{u}_{\mathrm{V}}$ refers to the uncertainty of the ice volume in entire Switzerland for the inventory year, which is 2016 (see Section 3.3). The uncertainty arising by homogenizing ice volumes to a given year $y$ is obtained from

$$
\bar{u}_{y}=\sqrt{\bar{u}_{\mathrm{V}}^{2}+\left(\bar{u}_{\mathrm{hom}}|y-2016| \frac{A_{y}+A_{2016}}{2}\right)^{2}},
$$

where $\bar{u}_{\mathrm{V}}$ is the uncertainty computed from Eqn (5), $A_{y}$ is the glacier area in the year $y$ and $A_{2016}$ the one in the reference year. The homogenization uncertainty $\bar{u}_{\text {hom }}$ is defined as the root-sum-square of the uncertainty of the long-term geodetic mass balances, estimated as $0.07 \mathrm{~m} \mathrm{a}^{-1}$ (Fischer and others, 2015), the effect of the uncertain extrapolation of the glacier area change on mass balance, estimated as $0.05 \mathrm{~m} \mathrm{a}^{-1}$, and the uncertainty related to the extrapolation of the year-to-year variability in mass balance to glaciers without data, estimated as $0.2 \mathrm{~m} \mathrm{a}^{-1}$.

\section{Results}

\subsection{GPR measurements}

In the framework of the current study, a total of $890 \mathrm{~km}$ of GPR profiles has been recorded during the years 2016 to 2019. Additionally, another $60 \mathrm{~km}$ were recorded in spring 2020, which have not been used for our ice thickness interpolation, but are used below in Section 5.2 for an independent validation of our ice thickness model results. Together with the GPR data of previous studies, there is now measured ice thickness along a total of around $2450 \mathrm{~km}$ of GPR profiles for the Swiss Alps (Table 1). These data were recorded on 251 different glaciers (red areas in Fig. 1a). Expressed in area, this is a coverage of 
Table 2. Twenty largest glaciers by volumes, for which GPR data were used for ice thickness modeling. A complete list of glaciers with GPR data is provided in the Supplementary material

\begin{tabular}{|c|c|c|c|c|c|c|c|c|c|}
\hline \multirow[b]{2}{*}{ SGI-id } & \multirow[b]{2}{*}{ Glacier name } & \multirow[b]{2}{*}{$A \mathrm{~km}^{2}$} & \multirow[b]{2}{*}{$V_{2016} \mathrm{~km}^{3}$} & \multicolumn{2}{|c|}{ Interpolation } & \multirow{2}{*}{$\begin{array}{c}d_{\text {mean-gpr }} \\
m\end{array}$} & \multirow{2}{*}{$\begin{array}{l}\text { Profile length } \\
\text { km }\end{array}$} & \multirow{2}{*}{$\begin{array}{c}\text { GPR survey } \\
\text { year(s) }\end{array}$} & \multirow{2}{*}{$\begin{array}{l}\text { GPR survey } \\
\text { references }^{a}\end{array}$} \\
\hline & & & & $h_{\text {mean }} \mathrm{m}$ & $h_{\max } \mathrm{m}$ & & & & \\
\hline B36/26 & Grosser Aletsch & 78.5 & 11.70 & 147 & 794 & 327 & 118.6 & 1958, 2009, 2011 & {$[3,16,27]$} \\
\hline B56/07 & Gorner & 41.2 & 3.71 & 91 & 385 & 810 & 34.4 & $1990-2012$ & {$[12,14,16,17]$} \\
\hline B40/07 & Fiescher & 29.8 & 3.52 & 117 & 437 & 648 & 17.8 & 2011 & {$[16,26]$} \\
\hline A54g/11 & Unteraar & 22.7 & 2.85 & 126 & 377 & 285 & 29.7 & 1086-2002, 2012 & {$[1,19,21,22]$} \\
\hline B43/03 & Rhone & 14.6 & 1.46 & 99 & 419 & 181 & 30.2 & 2003, 2008 & {$[4,19]$} \\
\hline $\mathrm{A} 51 \mathrm{~d} / 10$ & Huefi & 12.6 & 1.23 & 104 & 305 & 160 & 18.4 & 2018 & {$[8]$} \\
\hline B83/03 & Corbassiere & 14.9 & 1.22 & 82 & 247 & 425 & 31.4 & $1988,1998,2011$ & {$[7,16]$} \\
\hline B36/01 & Oberaletsch & 17.1 & 1.20 & 68 & 225 & 350 & 74.4 & 2009, 2011, 2017, 2019 & {$[8,27,31,32]$} \\
\hline B57/05 & Zmutt & 14.8 & 1.02 & 70 & 265 & 332 & 20.8 & 2012,2017 & {$[8,16]$} \\
\hline $\mathrm{A} 55 \mathrm{~b} / 13$ & Alpetli & 12.0 & 1.02 & 91 & 228 & 146 & 46.5 & 2012, 2019 & {$[8,16]$} \\
\hline B56/03 & Findelen & 13.9 & 1.01 & 74 & 206 & 254 & 29.5 & $2008,2012,2017$ & {$[8,12,16]$} \\
\hline E22/03 & Morteratsch & 14.9 & 0.90 & 61 & 281 & 225 & 25.5 & 2001, 2002, 2017 & {$[8,13]$} \\
\hline A54e/24 & Trift & 14.6 & 0.80 & 55 & 324 & 226 & 32.6 & 2002, 2008, 2012 & {$[16,19]$} \\
\hline $\mathrm{B} 82 / 27$ & Otemma & 12.6 & 0.78 & 62 & 256 & 533 & 19.7 & 2011, 2016 & {$[8,16]$} \\
\hline B63/05 & Zinal & 13.5 & 0.78 & 58 & 208 & 266 & 17.5 & 2007, 2010, 2016, 2017 & {$[8,11,19]$} \\
\hline B60/09 & Turtmann & 10.7 & 0.66 & 61 & 210 & 217 & 18.1 & 2012 & {$[16]$} \\
\hline A55f/03 & Raetzli & 7.3 & 0.64 & 87 & 208 & 57 & 47.3 & 2016,2017 & [8] \\
\hline A54l/19 & Untgrindelwald & 9.2 & 0.60 & 68 & 197 & 430 & 9.1 & 2019 & {$[8]$} \\
\hline B52/29 & Allalin & 9.1 & 0.58 & 64 & 242 & 327 & 32.1 & 1982, 2008, 2013, 2017 & {$[16,20]$} \\
\hline A54i/05 & Gauli & 10.8 & 0.57 & 53 & 253 & 405 & 36.5 & 2012 & {$[16,19]$} \\
\hline \multicolumn{2}{|c|}{215 further glaciers } & 385.3 & 17.5 & 36 & 300 & 175 & 928 & $1993-2020$ & {$[2,4-9,14-25,27-30]$} \\
\hline
\end{tabular}

The following information is provided: areas according to the SGI2016 $(A)$, volumes $\left(V_{2016}\right)$, mean thickness $\left(h_{\text {mean }}\right)$ and maximum thickness $\left(h_{\text {max }}\right)$ of the interpolated ice thickness distributions, mean distance to closest GPR point ( $\left.d_{\text {mean-gpr }}\right)$, total profile lengths, year of the GPR survey and the corresponding references for the GPR data. ${ }^{\mathrm{a} G P R}$ survey references: [1] Bauder and others (2003) ${ }^{\mathrm{b}}$; [2] Capt and others (2016) ; [3] Farinotti and others (2009a) after Thyssen and Ahmad (1969); [4] Farinotti and others (2009a) ${ }^{\mathrm{a}}$; [5] Feiger and others (2018) Fischer and others (2013) ${ }^{\mathrm{a}}$, Huss and Fischer (2016) ${ }^{\mathrm{a}}$; [7] VAW (1998) ${ }^{\mathrm{b}}$; [8] Grab and others (2020); [9] Grab and others (2020) acquired in 2020; [10] Huss (2010) ${ }^{\mathrm{a}}$; [11] Huss and others (2008) ; $^{\mathrm{a}}$. [12] unpublished GPR data from 2008 (ETHZ) and 2012 (UZH, UFR) ; [13] Huybrechts and others (2008); [14] Lüthi (2000) ; [15] Moll (2012) $;$; [16] Rutishauser and others (2016) $)^{\mathrm{a}}$; [17] Sugiyama and others (2008) ${ }^{\mathrm{a}}$; [18] unpublished GPR data form UFR ${ }^{\mathrm{a}}$; [19] unpublished GPR data ETHZ $;$; [20] Waechter and Roethlisberger (1982) ${ }^{\mathrm{b}}$; [21] Roethlisberger and Funk (1987) ${ }^{\mathrm{b}}$; [22]

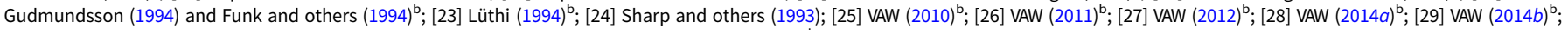
[30] VAW (2017a); [31] VAW (2017b); [32] VAW (2019) ${ }^{a}$ retrieved from GlaThiDa Consortium (2019), ${ }^{b}$ retrieved from GLAMOS (2020a).

$81 \%$ and it comprises $93 \%$ of the total glacier ice volume, computed from the volume estimate of our study. This is a remarkably high coverage. To our knowledge, such a comprehensive coverage of ice thickness observations exists for Iceland (Björnsson and Pálsson, 2020) but not for other glacierized mountain ranges at a regional scale (here almost $1000 \mathrm{~km}^{2}$ of glacier area). Nevertheless, not all glaciers could be surveyed in an optimal manner, for example with regard to data quality, and with the desired density of observations. To visualize the heterogeneity of the data coverage, we computed the mean of the distances of each point on a glacier to the closest GPR point measurement, $d_{\text {mean-gpr }}$. Resulting values are listed in Table 2 and in the Supplementary material and displayed color-coded in Figure 1. The highest coverage (among the larger glaciers) exists for Glacier de la Plane Morte (A55f/03) with a distance of $57 \mathrm{~m}$ to the closest GPR point. The lowest coverages were found for the large glaciers Fieschergletscher (B40/07), and Gornergletscher (B56/07), the latter with the highest value of $810 \mathrm{~m}$. Averaging $d_{\text {mean-gpr }}$ over all glaciers with GPR data results in $187 \mathrm{~m}$. The actual location of GPR survey points is displayed in gray in Figure 1b. For Fieschergletscher with its relatively low coverage, we, for example, observe that the large parts of the glacier located on steep slopes have not been surveyed.

\subsection{Ice thickness distribution and glacier bed topography}

The ice thickness distribution resulting from Eqn (1) is illustrated in Figure $4 \mathrm{a}$ for the example region of the Bernese Alps. In this region, Grosser Aletschgletscher (B36/26 in Fig. 1), the largest glacier of the European Alps, reaches a maximum ice thickness of $790 \mathrm{~m}$. Subtracting the ice thickness from the DEM yields the glacier bed topography. This is shown as hillshade in Figure 4b. Parts of the glacier bed topography, which feature overdeepenings, are displayed in red colors, with the color-code indicating the overdeepening depth. For other regions of the Swiss Alps, analogous figures are provided in the Supplementary material.

\subsubsection{GlaTE-, ITVEO- and MEAN performance}

A comparison between modeled and measured ice thickness as well as a comparison among GlaTE, ITVEO and MEAN is shown exemplarily in Figure 5 for Kanderfirn, Tschingelfirn and Blüemlisalpgletscher (glaciers marked with IDs A55b/13, A54m/21 and A55b/02 in Fig. 1b). Profiles 3, 7 and 45 are three sections along GPR profiles (Figs $5 \mathrm{~b}$ to $\mathrm{d}$ ). Comparisons from all other, not shown, profiles reveal similar insights: in general, we observe a smaller amount of structural details in the modeled ice thickness distributions in comparison with the ice thickness measured with GPR (e.g. Fig. 5c). This is related to the limited resolution of the models (10 $\mathrm{m}$ grid size). One could argue that interpolation could be performed on an even denser grid. However, to avoid the appearance of artificial structural details within the large space in-between GPR profiles, a smoothing constraint had to be applied to both models. This counteracts the ability to fit the GPR data, independently from the grid resolution. In most cases, the models fit the measured ice thicknesses well within the measurement uncertainty, indicating that an adequate weight was given to the smoothness constraint. At the glacier margins and especially at the glacier tongues, ice thickness measured with GPR sometimes exhibit larger values than the modeled ice thickness (Fig. 5b). This is because some weight is given to the model boundary constraints, which force the models to approach zero ice thickness toward the glacier margins.

Intercomparing the performance of GlaTE and ITVEO, we observe only small differences between the two models within GPR cross sections. Generally, the GlaTE model converged to a slightly smoother ice thickness distributions compared to ITVEO (e.g. Fig. 5d). This is a result of the somewhat less restrictive constraints of the GlaTE model, which only targets for a fit of 

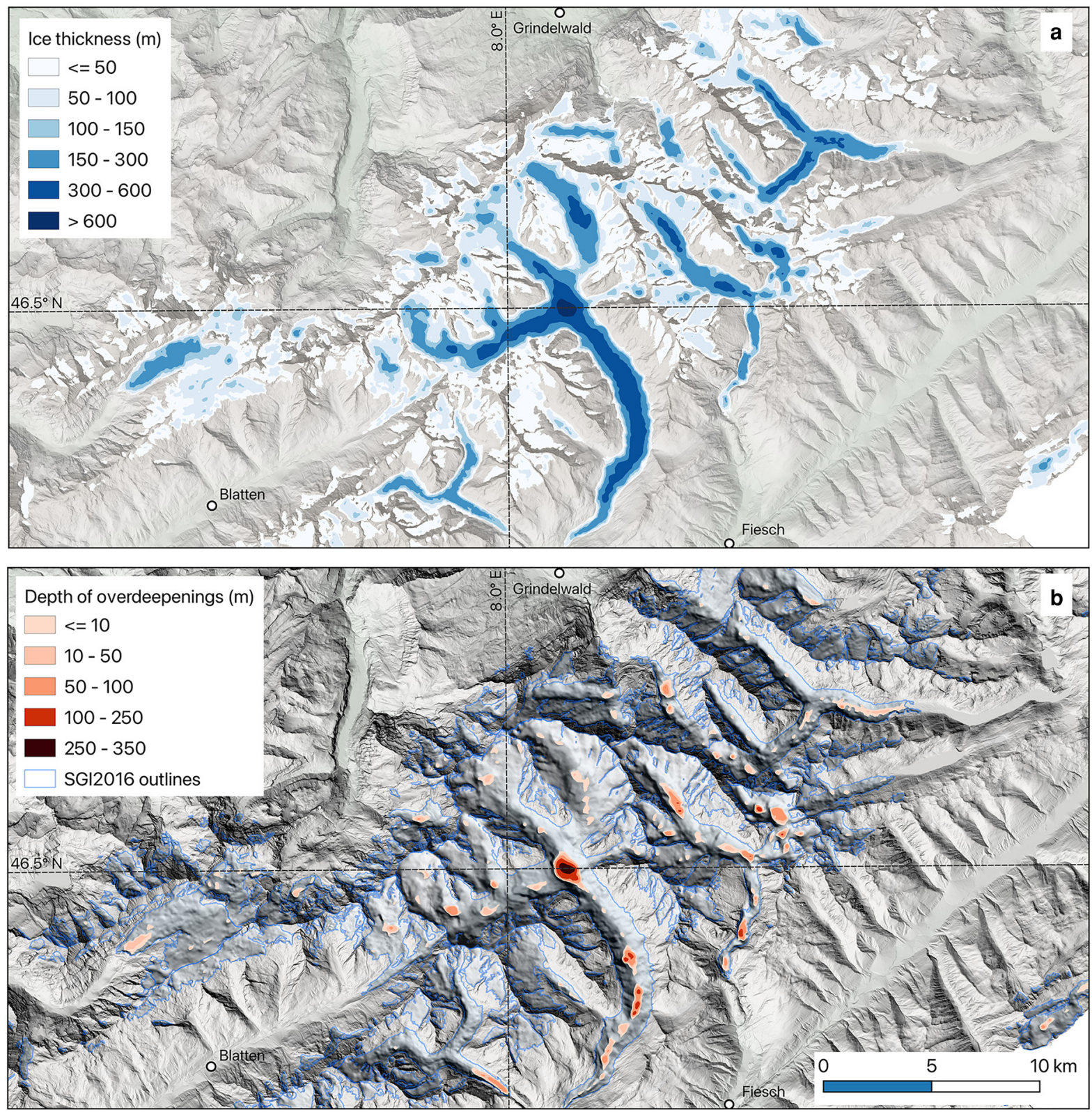

Fig. 4. Ice thickness and glacier bed overdeepenings in the Bernese Alps (see box in Fig. 1): (a) ice thickness distribution. (b) Hillshade of the glacier-bed topography within SGI2016 outlines and color-coded the depth of overdeepenings. For other parts of the Swiss Alps, see the Supplementary material. Background: hillshade from the swissALTI3D after Swisstopo (2019).

95\% of the cells with GPR data (Langhammer and others, 2019a), and was, thus, obtained at the expense of a somewhat poorer GPR fit. For comparing GlaTE and ITVEO at locations not covered by the GPR profiles, a transverse (A) and longitudinal (B) cross section, as well as a section across an ice divide (C), is shown in Figures 5e-g. Furthermore, a transverse cross section on Blüemlisalpgletscher (D) is shown in Figure 5h, for which no GPR data exist at all. As expected, the ice thicknesses of the two models deviate more in these cases than along GPR profiles, with differences of up to $\sim 25 \%$ of the local ice thickness for the sections on glaciers with GPR data and up to $\sim 35 \%$ for the glacier without any GPR data. In many cases, the ice thickness of GlaTE is larger than the one of ITVEO in the vicinity of the glacier margins, as can be seen in Figures $5 \mathrm{f}$ and $\mathrm{h}$. This indicates a slight tendency toward more U-shaped cross sections for GlaTE and toward more V-shaped cross sections for ITVEO. For MEAN, however, pronounced features of the individual models are averaged out, yielding higher robustness against artificial structures that are not evident in the measured ice thickness.
For comparing the ice thickness distribution obtained by modeling with the measured GPR data, modeled ice thickness values were bilinearly interpolated and extracted for the exact GPR locations. Averaged over the entire Swiss Alps, the modeled values fit within the measurement uncertainty for around $85 \%$ of the GPR-locations (83\% for GlaTE and 86\% for ITVEO). As discussed above for the example shown in Figure 5, the main reasons for not fitting the remaining $15 \%$ of GPR data are (1) the limited resolution of the models in combination with smoothness constraints, (2) the model boundary constraints which sometimes contradict with the measured ice thickness values, and, in a few cases, (3) contradictory measurements between GPR data from different sources. The latter could not be avoided because the GPR raw data were not available to judge on the reason for the contradiction.

\subsubsection{Uncertainty of interpolated ice thicknesses}

For each point $(x, y)$ of the interpolated ice thickness map, the standard uncertainty $u^{ \pm}(x, y)$ is estimated from Eqn (3). An example of the resulting uncertainty distribution is presented in 

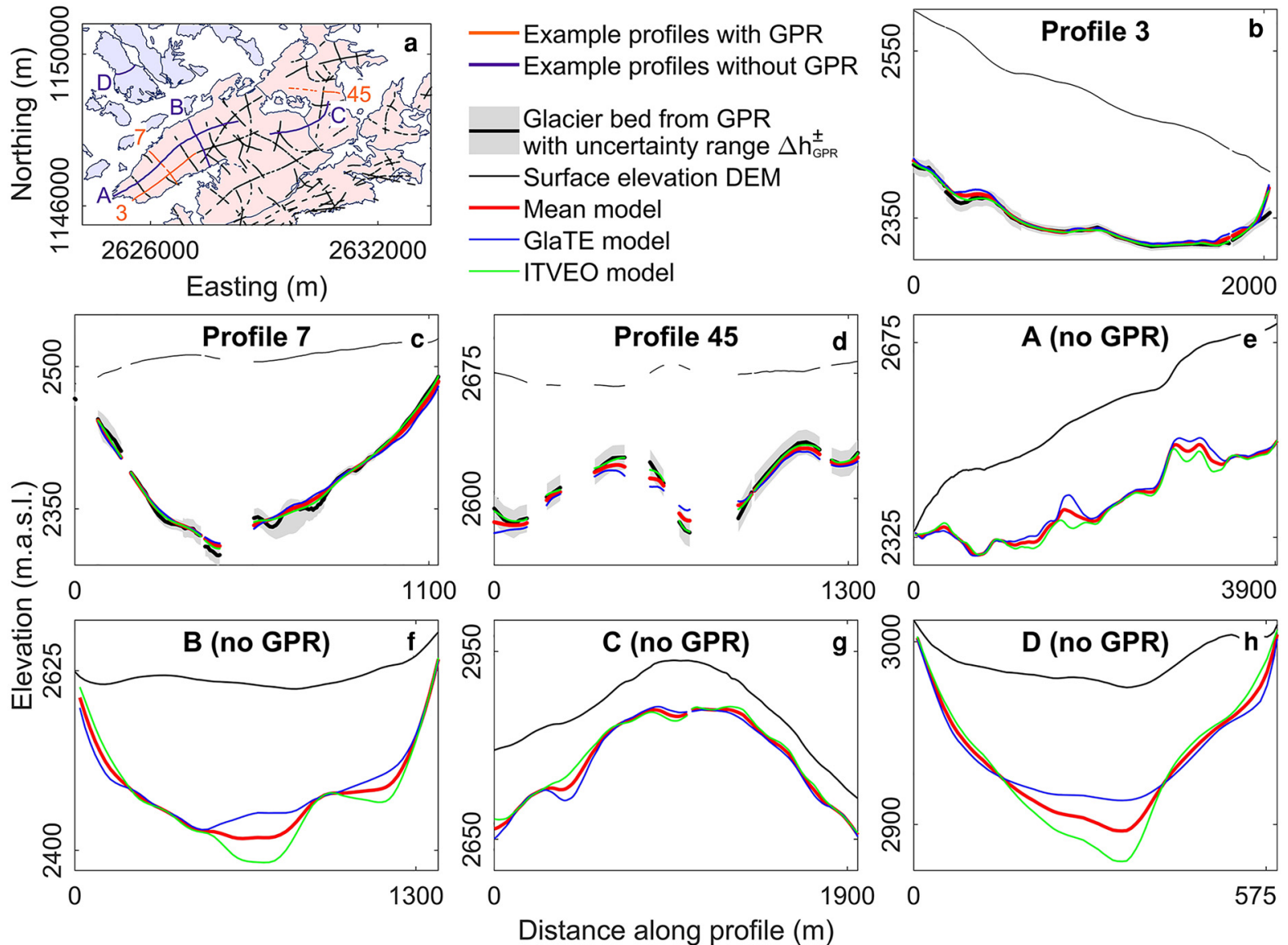

Fig. 5. Comparison of glacier bed elevations measured with GPR with modeled glacier bed elevations from MEAN, GlaTE and ITVEO. (a) Map of the region (see also Fig. 1). Location of the selected GPR profiles are shown in orange together with locations of all other profiles measured on these glaciers in black. The purple profiles are transects without GPR data. (b)-(d) Comparison of glacier bed elevations along the selected GPR-profiles. (e)-(h) Comparison of glacier bed elevations along transects without GPR data.

Figure 6 for Brunnifirn, a small glacier in central Switzerland (glacier A51d/15 in Fig. 1a). This glacier was selected because some pronounced measurement-uncertainty occur in GPR profile 1 . The ice thickness distribution from Brunnifirn reveals ice thicknesses up to $\sim 140 \mathrm{~m}$ (Fig. 6a). The GPR data recorded along profile 1 is displayed in Figure 6b, together with its interpreted ice thickness profile shown in Figure 6c. Due to ambiguous reflections in the upper part of this profile, there are large uncertainties in the measured ice thickness. How this impacts the uncertainty of the ice thickness distribution toward smaller and larger ice thickness is presented in Figures $6 \mathrm{~d}$ and h, respectively. The contribution from the individual error sources, interpolation uncertainty, GPR-uncertainty, and surface elevation uncertainty are displayed in Figures $6 \mathrm{e}-\mathrm{g}$ and $\mathrm{i}-\mathrm{k}$. We observe the lower uncertainty bound to be strongly dominated by the GPR-uncertainty due to the large measurement uncertainty in profile 1 toward smaller ice thickness. In contrast, the GPR-uncertainty toward larger ice thickness is relatively small. Therefore, the interpolation uncertainty is the quantity dominating the upper uncertainty bound for the example of Brunnifirn.

For validating our point-specific uncertainty estimates, we compare $u^{ \pm}(x, y)$ with the uncertainty intervals $\Delta h_{\mathrm{GPR}}^{ \pm}$of measured ice thicknesses $h_{\mathrm{GPR}}$ acquired on 33 glaciers in the spring 2020 campaigns. These are data that had not been used for the ice thickness interpolation. For nine of these glaciers, older GPR data already existed and have been used for the ice thickness interpolation, whereas for the other 24 glaciers, no data were available before. We find that (i) for $39 \%$ of the points, $\Delta h_{\mathrm{GPR}}^{ \pm}$ is entirely within $u^{ \pm}(x, y)$, (ii) for $25 \%$ of the points, $h_{\mathrm{GPR}}$ falls within $u^{ \pm}(x, y)$ but not the entire interval $\Delta h_{\mathrm{GPR}}^{ \pm}$, (iii) for $17 \%$ of the points, $h_{\mathrm{GPR}}$ is outside $u^{ \pm}(x, y)$ but part of $\Delta h_{\mathrm{GPR}}^{ \pm}$is overlapping with $u^{ \pm}(x, y)$ and (iv) for $19 \%$ of the points, there is no overlap of the uncertainty ranges at all. Compliance, that is, the measurement falls within the modeling uncertainty range, is assumed for both cases (i) and (ii), whereas non-compliance is assumed for both cases (iii) and (iv). From this follows that $u^{ \pm}(x, y)$ accommodates a total of $39+25=64 \%$ of the measured ice thicknesses, which is in good agreement of $u^{ \pm}(x, y)$ being the standard uncertainty, which by definition is expected to encompass $\sim 68 \%$ of the true ice thickness. For glaciers previously without GPR data, the compliance percentage is similar (66\%) to the one for glaciers which already had GPR data (62\%).

\subsection{Total ice volume in the Swiss Alps}

Summing over all glaciers, we find a total ice volume of $59.31 \mathrm{~km}^{3}$ for the MEAN model and the respective inventory year of all individual glaciers. The volumes resulting from the GlaTE and ITVEO models are almost identical, being 59.30 and $59.32 \mathrm{~km}^{3}$, respectively. This high agreement is accidental. In fact, the two models differ slightly more when differentiating between glacier size classes. After homogenization, we find a total ice volume in the Swiss Alps for the year 2016 of $V_{2016}=58.8 \pm 2.5 \mathrm{~km}^{3}$. For the magnitudes of the uncertainty components for the total ice volume we find $\bar{u}_{\text {int }}=0.24 \mathrm{~km}^{3}, \bar{u}_{\mathrm{w} / \text { gpr }}=0.14 \mathrm{~km}^{3}, \bar{u}_{\mathrm{w} / \mathrm{ogpr}}=$ $2.44 \mathrm{~km}^{3}, \bar{u}_{\text {area }}=0.30 \mathrm{~km}^{3}$ and $\bar{u}_{\text {surf }}=0.54 \mathrm{~km}^{3}$. Substituting into Eqn (5), it results an uncertainty of $\bar{u}_{\mathrm{V}}= \pm 2.54 \mathrm{~km}^{3}$ or of $4.3 \%$, respectively. 

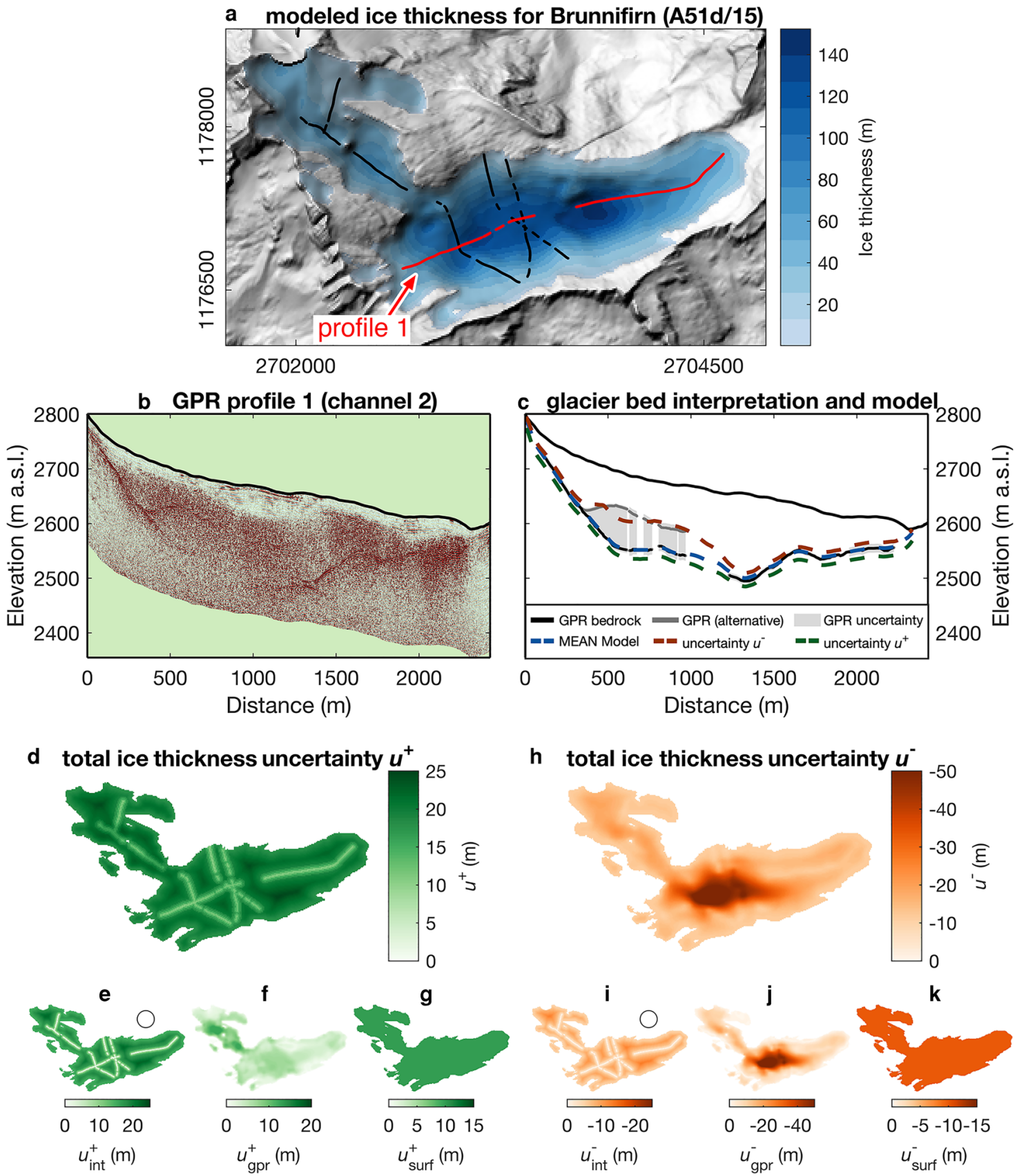

Fig. 6. Brunnifirn as an example for estimating point-specific ice thickness uncertainties. (a) Ice thickness distribution with GPR-profile locations. (b) Example GPR-profile and (c) corresponding glacier bed interpretation with uncertainties of the GPR measurement, comparison with the ice thickness model and the model uncertainty. Total ice thickness uncertainty toward larger (d) and smaller (h) ice thickness and the corresponding contribution from interpolation- $\left(u_{\text {int }}^{ \pm}\right)$, GPR- $\left(u_{\text {gpr }}^{ \pm}\right)$and surface DEM-uncertainties $\left(u_{\text {surf }}^{ \pm}\right)$in the small subpanels (e)-(g) and (i)-(k). The circles shown in (e) and (i) indicate over which distances $u_{\text {int }}^{ \pm}$, is expected to spatially correlate (see Section D).

To investigate, how the uncertainty of glaciers of different size and with/without GPR data contribute to the total ice volume uncertainty (for individual glaciers see Fig. S13 in the Supplementary material), the cumulative uncertainty $\bar{u}_{\mathrm{V}}$ is consecutively calculated from Eqn (5) for all glaciers with average ice thickness up to a certain size (Fig. 7a). The cumulative ice volume for glaciers with and without GPR data, and the cumulative glacier area, are displayed in Figure $7 \mathrm{~b}$. It becomes evident that the predominant part of the volume uncertainty stems from glaciers with average ice thicknesses $<50 \mathrm{~m}$, although they only account for around one quarter of the total ice volume. The main factor controlling the uncertainty of these smaller glaciers is $\bar{u}_{\mathrm{w} / \mathrm{ogpr}}$, that is the uncertainty of calibrating the ice thickness models for glaciers without GPR data. For all other glaciers, for which GPR data have been acquired, $\bar{u}_{\text {surf }}$ is the most important contribution to the uncertainty, followed by $\bar{u}_{\text {area }}, \bar{u}_{\text {int }}$ and $\bar{u}_{\mathrm{w} / \mathrm{gpr}}$.

\section{Discussion}

\subsection{Ice volumes from earlier studies}

The total ice volume in the Swiss Alps resulting from our study is $V_{2016}=58.7 \pm 2.5 \mathrm{~km}^{3}$ and, when extrapolating the ice volume to $2020, V_{2020}=52.9 \pm 2.7 \mathrm{~km}^{3}$. Earlier estimates of the Swiss glacier volume were presented in various studies based on the glacier inventories of 1973 (Muller and others, 1976; Maisch, 2000), 1999 (Farinotti and others, 2009a; Linsbauer and others, 2012) and 2010 (Fischer and others, 2015). Furthermore, Farinotti and 

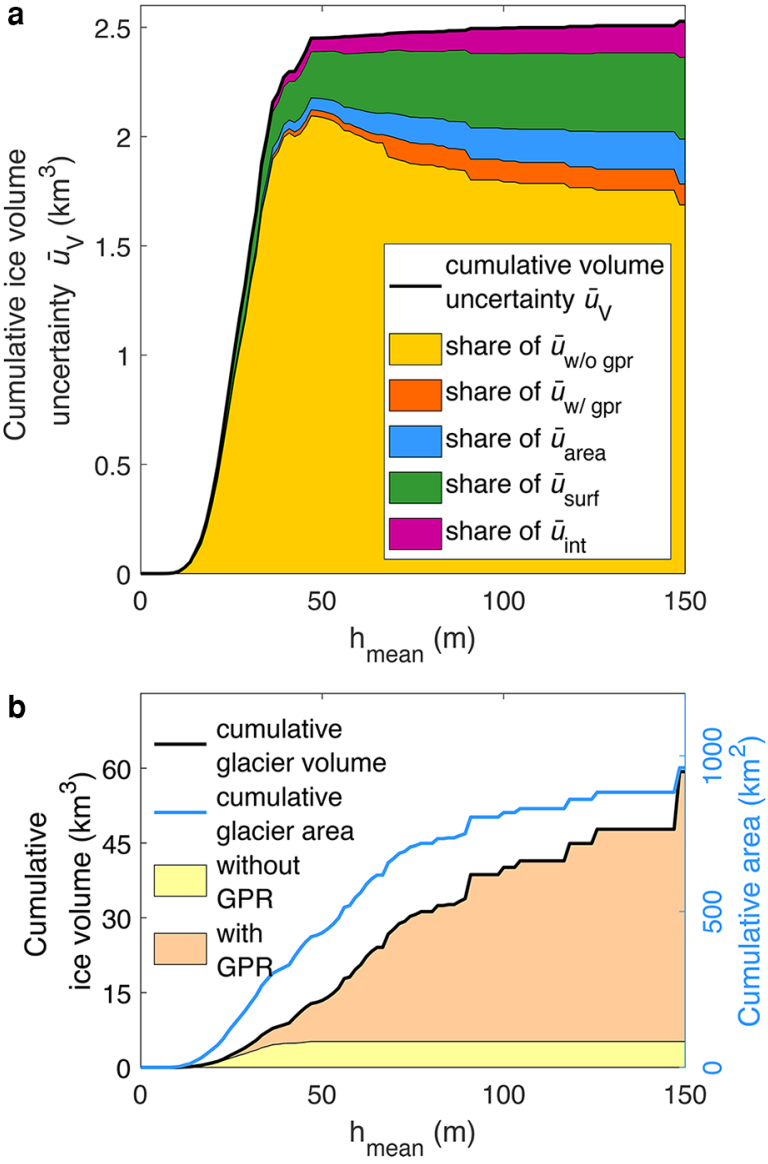

Fig. 7. (a) Overall ice volume uncertainties and share of the different uncertainty components computed by cumulating all glaciers according to their average ice thickness. (b) Cumulative ice volume for glaciers with and without GPR data, and cumulative glacier area.

others (2019) estimated the total ice volumes in the European Alps for the year 2003 and Haeberli and others (2019) for the year 2018. The corresponding volume estimates are displayed in Figure 8. Based on empirical relationships between glacier area and mean ice thickness, Muller and others (1976) estimated a volume of $67 \mathrm{~km}^{3}$ and Maisch (2000) of $74 \mathrm{~km}^{3}$ for the year 1973. Estimations based on measured ice thickness for a subset of glaciers combined with modeled ice thickness have been obtained by Farinotti and others $(2009 a)$ with $75 \pm 9 \mathrm{~km}^{3}$ and Linsbauer and others (2012) with $65 \pm 20 \mathrm{~km}^{3}$ both for the year 1999 , and by Fischer and others (2015) with $60 \mathrm{~km}^{3}$ referring to the year 2010.

First of all, it is noteworthy that our estimated uncertainty is clearly smaller than the one by Farinotti and others (2009a) and Linsbauer and others (2012), which we attribute to the larger amount of ice thickness data used compared to previous studies. Furthermore, when homogenizing our results to the corresponding years of the previous estimates we find ice volumes of $65.2 \pm 2.8 \mathrm{~km}^{3}$ (2010), of $77.2 \pm 4.6 \mathrm{~km}^{3}$ (1999) and of $94.0 \pm 10.9 \mathrm{~km}^{3}$ (1973) (Fig. 8). This indicates that the early studies by Muller and others (1976) and Maisch (2000) likely underestimated the volumes that were present in the 1970s in comparison with our results. High agreement was found with the estimate by Farinotti and others (2009a) with a discrepancy of only $\sim 2 \mathrm{~km}^{3}$. Also for the study by Linsbauer and others (2012) the error bars overlap, although their ice volume estimate is substantially lower by $\sim 12 \mathrm{~km}^{3}$. The estimate by Fischer and others (2015) for the year 2010 is close to our estimate but again slightly lower by $\sim 5 \mathrm{~km}^{3}$, which might be due to the somewhat underestimated glacier area in their inventory (Fischer and others, 2014) in comparison with the SGI2016 (GLAMOS, 2020b). Huss and
Farinotti (2012) estimated that Swiss glaciers contribute with 58.7\% to the total ice volume of the European Alps. Based on this percentage, the volume estimate by Farinotti and others (2019) is equivalent to 75 $\pm 18 \mathrm{~km}^{3}$ for the year 2003 , which closely fits our estimate for the corresponding year. For Haeberli and others (2019) it is equivalent to 49 $\pm 15 \mathrm{~km}^{3}$, which is lower by $\sim 6 \mathrm{~km}^{3}$ in comparison with our results.

It is apparent from Figure 8 that from the newer studies, the ones by Linsbauer and others (2012) and by Haeberli and others (2019) tend to underestimate the ice volumes with respect to other recent estimates and the result of our assessment. It is difficult to investigate whether such differences are related to the ice thickness observations that were available for constraining the individual estimates, or whether they can be attributed to the different type of ice thickness model used. Model types differing from GlaTE and ITVEO are for instance models based on the shallow ice approximation (e.g. Linsbauer and others, 2012) or 2-D approaches based on the continuity equation (e.g. Morlighem and others, 2011) and on the parallel ice sheet model (e.g. Van Pelt and others, 2013). Although ITMIX2 (Farinotti and others, 2021) does not provide a direct answer in our case, no significant differences in performance or biases regarding computed ice thickness between models of different types were found. Overall, ITMIX2 revealed no drift in the modelderived ice thicknesses when restricting the input to fewer observational data. This was the case for both, individual models and the model ensemble. The absence of such a drift indicates that our ice volume estimate at the mountain-range scale is relatively robust with regard to the model types. Therefore, we expect only minor discrepancies in the total ice volume if another model type would have been constrained with the comprehensive set of ice thickness data available today. It is probable, however, that the model type has a larger impact on the volume estimate of individual glaciers or the ice thickness distribution at the local scale. Within the ITMIX2 experiment, GlaTE and ITVEO were part of the group of models giving preference to the reproduction of observational data over internal model consistency. Therefore, including a model that emphasizes internal model consistency might improve our results for glaciers with sub-optimally distributed point observations. Such a model is for instance the one presented by Van Pelt and others (2013), which showed a strong performance in ITMIX2.

As introduced in Section 3.3 and presented in Figure 8, our homogenization approach also allows extrapolating the overall ice volume of Swiss glaciers backward in time. Our results indicate a volume of $65.2 \pm 2.8 \mathrm{~km}^{3}$ in $2010,76.5 \pm 4.4 \mathrm{~km}^{3}$ in 2000 and $95.1 \pm 9.0 \mathrm{~km}^{3}$ in 1980 . This indicates that $\sim 0.9 \mathrm{~km}^{3} \mathrm{a}^{-1}$ ice were lost between 1980 and 2000, $1.1 \mathrm{~km}^{3} \mathrm{a}^{-1}$ between 2000 and 2010 and $1.2 \mathrm{~km}^{3} \mathrm{a}^{-1}$ between 2010 and 2020 . With reference to the earlier ice volumes, it is $\sim 43 \%$ of the Swiss glacier volume that has been lost over the last 40 years, $29 \%$ within the last 20 years and around $17 \%$ within the last 10 years. These relative ice volume changes confirm the recent acceleration of glacier mass loss presented for example by Zemp and others (2015) and Beniston and others (2018).

\subsection{GPR data coverage}

The measured ice thickness forming the basis of our study will be publicly available. For some of the older data this is already the case through database GlaThiDa (GlaThiDa Consortium, 2019) and for all the new data and some data from older studies it is made available in the framework of the study presented here. As displayed in Figure 1, these data cover the overwhelming part of the glacierized areas in the Swiss Alps. Our uncertainty analysis, however, shows that the few glacier areas remaining without GPR data contribute the most to the uncertainty in the 


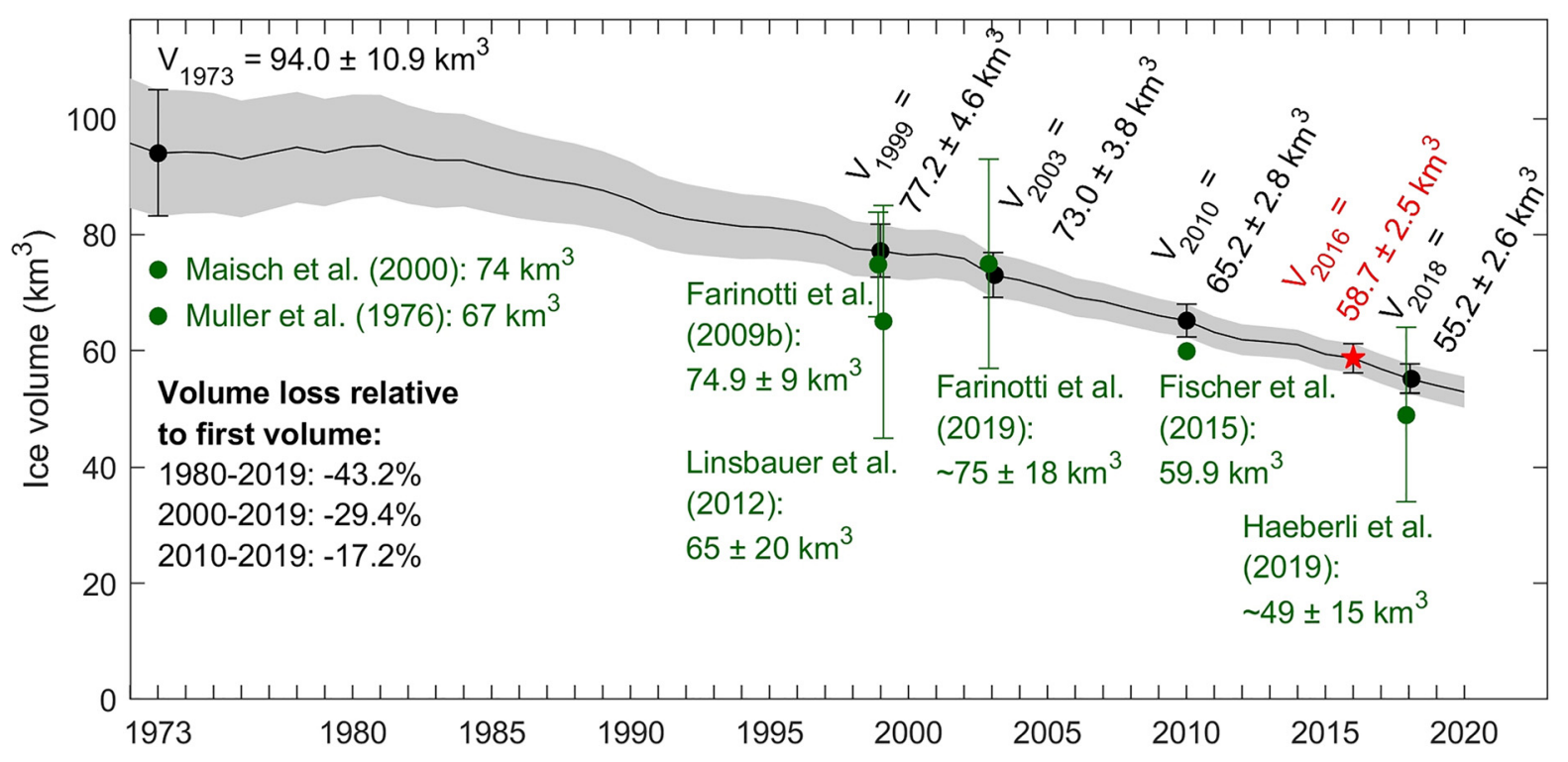

Fig. 8. Temporal extrapolation of the total ice volume in Swiss glaciers for the period 1973-2020 (black curve with gray uncertainty range from Eqn 6) based on the overall volume in 2016 inferred in the current study (red asterisk), see Section 3.3 for details. The time series of overall glacier volume allows direct comparison to previous ice volume estimates for the Swiss Alps (green).

Swiss-wide total ice volume due to the uncertainty in model calibration for those glaciers. Therefore, performing GPR-campaigns on the largest glaciers remaining without GPR data to date, would be the most effective option for further reducing this uncertainty. The largest glacier (in volume) without GPR data is Dammagletscher (marked with ID A51f/10 in Fig. 1) with an area of $3.8 \mathrm{~km}^{2}$ and an estimated volume of $0.12 \mathrm{~km}^{3}$. A list with the largest glaciers without GPR data is given in the Supplementary material.

The uncertainty arising from the interpolation procedure between the sparse grid of GPR-measurement locations contributes relatively little to the overall uncertainty of our total ice volume estimate. Therefore, we conclude that no further refinement of the GPR coverage would be required for future volume estimates or similar studies focusing on scales beyond the one of individual glaciers. Recommendations about survey layouts at such scales was deduced from our earlier study (Langhammer and others, 2019a) where we proposed cost-optimized GPR survey layouts.

The interpolation uncertainty contributes significantly to the point-specific uncertainty in ice thickness as, for example, shown in Figure 6d. For specific studies on smaller scales, it might therefore be recommendable to acquire GPR data on denser grids than we have typically done. An example for such a survey is a detailed study that we have performed on the tongue of Oberaletschgletscher, for which data were acquired on a dense grid with around $70 \mathrm{~m}$ profile-interspacing as shown in Figure 1 (Oberaletschgletscher marked with ID B36/01).

\subsection{Ice thickness distribution and glacier bed topography}

The ice thickness maps and the glacier bed topography maps resulting from our study are made publicly available as well. We anticipate these data to be of value for various further glaciological investigations or studies in related fields. For example, the study of Gabbi and others (2012) investigated river runoff projections using a glacio-hydrological model that requires detailed information about the ice thickness distribution as a function of elevation and slope exposition. It was frequently stressed that more accurate ice thickness data are the most important factor for reducing the uncertainty in long-term projections of glacier retreat and corresponding changes in the runoff regime (e.g. Huss and others, 2014), for example to obtain the precise timing of maximum glacier melt volumes (Schaefli and others, 2019), or to better predict future hydropower revenue (Gaudard and others, 2016). From our data, for example, the total ice volume for individual river catchments and across different elevation bands can be calculated (see Supplementary material). It is important to note here that we homogenized the ice volumes but not the ice thickness distributions. The latter are given for the inventory years defined by the DEM (swissALTI3D and r2019) and thus exhibit some heterogeneity. For this reason, we also deliver the meta data, which provides the inventory year in the form of raster data (Supplementary Fig. S11).

The maps of glacier bed topography provide information on the future valley morphology forming after glacier retreat, which is expected to further accelerate in the coming decades (Zekollari and others, 2019). Such a map, for example, contains information on glacier bed overdeepenings, which can be further analyzed with regard to their potential for the formation of future proglacial lakes. Based on the glacier bed topography and the distribution of today's ice volume, various studies have aimed at predicting the size and the formation time of such lakes in the Alps (Frey and others, 2010; Linsbauer and others, 2012; Gharehchahi and others, 2020; Magnin and others, 2020; Shugar and others, 2020). Such information is important since future lakes might change the hazard situation in the corresponding regions, or can be large enough to be of economic interest for tourism, fresh water supply or in the context of hydropower (Haeberli and others, 2016). We have thus analyzed the glacier bed map resulting from our study with regard to locations and volumes of overdeepenings. For the example region of the Bernese Alps, the location of anticipated overdeepenings is displayed in Figure $4 \mathrm{~b}$ with the color code indicating their depth. In comparison with the earlier study by Linsbauer and others (2012), there is a good agreement with regard to the locations where the most prominent overdeepenings occur. Computing the total volume of these overdeepenings across entire Switzerland results in a volume of around $1 \mathrm{~km}^{3}$ and delivers an estimate of future lake volumes. More than half of this lake volumes occur in the glacier beds of only four glaciers (Supplementary Fig. S9c). For the same glaciers except for Rhonegletscher, also Linsbauer and 
others (2012) observed large overdeepening volumes. The total volume, however, is substantially smaller than the lake volume of $\sim 2 \mathrm{~km}^{3}$ estimated by Linsbauer and others (2012). The discrepancy can to some degree be explained by the different modeling technique used by Linsbauer and others (2012) in comparison with the one used here. Nevertheless, since our results are based on substantially larger amounts of measured ice thickness data, it is likely that the total volume of lakes forming in the future in the Swiss Alps is smaller than previously assumed.

When referring to our glacier bed topography, it is important to note that it might also consist of unconsolidated sediment rather than bedrock. Reflections in the GPR images interpreted as the glacier bed, typically originate from the uppermost horizons with a pronounced GPR impedance contrast. In case of porous basal sediment layers saturated with liquid water or of a liquid water film on top of a well consolidated sediment deposit, such pronounced impedance contrasts occur at the base of the ice rather than at the base of the sediment layers. Thus, we expect that our glacier bed topography in general represents the topography at the base of the ice.

\section{Conclusions}

We have measured the ice thickness of all larger and most medium-sized $\left(\geq 0.02 \mathrm{~km}^{3}\right)$ glaciers of the Swiss Alps that had not been surveyed before, and we have refined the measurement grids on some of the glaciers with only partial surveys from previous studies. Together with the pre-existing data, measured ice thickness data are now available for 251 glaciers, which account for $81 \%$ of the glacierized area in the Swiss Alps. Altogether, these glaciers contain $93 \%$ of the total ice volume. With this comprehensive data coverage, our dataset has a great potential for various further investigations.

The measured ice thickness data, available only on the sparse grid of GPR profiles, were interpolated using two independent glaciological modeling techniques, GlaTE and ITVEO, together with the glacier outlines from the Swiss Glacier Inventory 2016 and the digital elevation model swissALTI3D-r2019. The use of more than one algorithm leads to a higher robustness of our results, in particular against interpolation artifacts. We obtained continuous ice thickness and glacier bed topography maps for all glaciers in the Swiss Alps at $10 \mathrm{~m}$ resolution, and estimated a total ice volume of $58.7 \pm 2.5 \mathrm{~km}^{3}$ for the year 2016 and of $52.9 \pm 2.7 \mathrm{~km}^{3}$ for 2020 . Thanks to the much more complete coverage of measurements, we were able to estimate the total ice volume, the ice thickness distribution and glacier bed topography with substantially lower uncertainty than in previous studies. The overall uncertainty is mainly controlled by the uncertainty in the ice volume of glaciers remaining without GPR data, which accounts for only $7 \%$ of the total ice volume. The volumes of these glaciers were estimated by extrapolating the model calibration from glaciers with GPR data to glaciers without GPR data.

Our results are accessible as the SwissGlacierThickness-R2020 data collection (Grab and others, 2020) for further use. This data collection also includes the ice thickness point data, which will be additionally available through a future release of GlaThiDa (Welty and others, 2020). We anticipate these data to be of value for various further studies, as, for example, investigations of river runoff projections, or for predicting locations and volumes of proglacial lakes that will occur in the course of glacier retreat. An analysis of our glacier bed topography maps, for example, revealed that the volume of such lakes forming in the future in the Swiss Alps is probably smaller than it was assumed from earlier studies.

Supplementary material. The supplementary material for this article can be found at https://doi.org/10.1017/jog.2021.55
Data and code accessibility. All ice thickness point-data measured with GPR, if not published on GlaThiDa 3.0.1 and except the once presented by Huybrechts and others (2008) and Sharp and others (1993), are publicly accessible from the ETH Zurich Research Collection as the SwissGlacierThicknessR2020 data package (Grab and others, 2020, https://doi.org/10.3929/ethz-b000434697). The same accounts for the raster data of the modeled ice thickness and of the glacier bed elevations together with the meta data. SwissGlacierThickness-R2020 contains the following datasets:

(1) Ice thickness measured with GPR and estimation of measurement uncertainty for the entire Swiss Alps and for each glacier (ASCII and SHP)

(2) Ice thickness map, valid for the inventory years (after swissALTI3D (r2019) metadata) for the entire Swiss Alps and for each glacier (TIF)

(3) Ice thickness uncertainty map for the entire Swiss Alps and for each glacier (TIF)

(4) Map with inventory year of each ice thickness model cell, according to metadata of swissALTI3D (r2019), for the entire Swiss Alps and for each glacier (TIF)

(5) Glacier bed map for the entire Swiss Alps and for each glacier (TIF)

The data formats are given in brackets, with 'ASCII' indicating ascii text files, 'SHP' indicating shape files and 'TIF' indicating geo-tiff files.

A Matlab implementation of GlaTE, together with test datasets was described by Langhammer and others (2019a). An updated version according to the current study is available at https://gitlab.com/hmaurer/glate.

Acknowledgments. The authors thank Beat Rinderknecht from BRTECHNIK and Christoph Bärlocher from ETH Zurich for constructing the GPR platform with great inventiveness and technical know-how, and Patrick Fauchère (also involved in the development phase) from Air Glacier and Hansueli Bärfuss from Heli Bernina for their passionate support in planning and conducting the field campaigns. Many thanks also go to Martin Funk, who supported us at the beginning of this project as the head of the Glaciology group at ETH Zurich. Under his lead, in cooperation with Norbert Blindow, and financed by the canton of Valais, helicopter-borne GPR campaigns were conducted on numerous glaciers in the Valais Alps, which motivated us to conduct the work presented here. At the same time, a data management was initiated by Yvo Weidmann, what was of great help during the entire course of our study. Fabian Amman with his master thesis, Pascale Carlen with her bachelor thesis, and Hendrik Pormes and Serafine Kattus during their student internships contributed to the work presented in this study. Financial support was provided by the Swiss Geophysical Commission SGPK, the Swiss Competence Center for Energy Research Supply of Electricity (SCCER-SoE, Innosuisse), the Swiss National Science Foundation (grant numbers 200021_169329/1 and 200021_169329/2), and by ETH Zurich.

\section{References}

Allen C, Leuschen C, Gogineni P, Rodriguez-Morales F and Paden J (2010) IceBridge MCoRDS L2 Ice Thickness. http://nsidc.org/data/irmcr2.html, National Snow Ice Data Center, Boulder, Colorado.

Andreassen LM, Huss M, Melvold K, Elvehøy H and Winsvold SH (2015) Ice thickness measurements and volume estimates for glaciers in Norway. Journal of Glaciology 61(228), 763-775. doi: 10.3189/2015JoG14J161.

Bahr DB, Pfeffer WT and Kaser G (2015) A review of volume-area scaling of glaciers. Reviews of Geophysics 53(1), 95-140. doi: 10.1002/2014RG000470.

Bauder A, Funk M and Gudmundsson GH (2003) The ice-thickness distribution of Unteraargletscher, Switzerland. Annals of Glaciology 37, 331-336. doi: 10.3189/172756403781815852.

Beniston M (2012) Impacts of climatic change on water and associated economic activities in the Swiss Alps. Journal of Hydrology 412, 291-296. doi: $10.1016 /$ j.jhydrol.2010.06.046.

Beniston M and 24 others (2018) The European mountain cryosphere: a review of its current state, trends, and future challenges. The Cryosphere 12(2), 759-794. doi: 10.5194/tc-12-759-2018.

BFE (2019) Swiss Federal Office for Energy, Swiss Electricity Statistics 2019. https://www.bfe.admin.ch/bfe/en/home/supply/statistics-and-geodata/energystatistics/electricity-statistics.html, Accessed 27 November 2020.

Bingham RG and Siegert MJ (2007) Radio-echo sounding over polar ice masses. Journal of Environmental and Engineering Geophysics 12(1), 47-62. doi: 10.2113/JEEG12.1.47. 
Björnsson H and Pálsson F (2020) Radio-echo soundings on Icelandic temperate glaciers: history of techniques and findings. Annals of Glaciology 61(81), 25-34. doi: 10.1017/aog.2020.10.

Blindow N, Salat C, Gundelach V, Buschmann U and Kahnt W (2011) Performance and calibration of the helicopter GPR system BGR-P30. In 2011 6th International Workshop on Advanced Ground Penetrating Radar (IWAGPR) pp. 1-5. doi: 10.1109/IWAGPR.2011.5963896.

Blindow N, Salat C and Casassa G (2012) Airborne GPR sounding of deep temperate glaciers - Examples from the Northern Patagonian Icefield. In 2012 14th International Conference on Ground Penetrating Radar (GPR) pp. 664-669. doi: 10.1109/ICGPR.2012.6254945).

Braun L, Weber M and Schulz M (2000) Consequences of climate change for runoff from Alpine regions. Annals of Glaciology 31, 19-25. doi: 10.3189/ 172756400781820165.

Brinkerhoff DJ, Aschwanden A and Truffer M (2016) Bayesian inference of subglacial topography using mass conservation. Frontiers in Earth Science 4(8), 1-15. doi: 10.3389/feart.2016.00008.

Capt M, Bosson JB, Fischer M, Micheletti N and Lambiel C (2016) Decadal evolution of a very small heavily debris-covered glacier in an Alpine permafrost environment. Journal of Glaciology 62(233), 535-551. doi: 10.1017/jog. 2016.56.

Christensen EL and 5 others (2000) A low-cost glacier-mapping system. Journal of Glaciology 46(154), 531-537. doi: 10.3189/172756500781833142.

Clarke GK and 6 others (2013) Ice volume and subglacial topography for western Canadian glaciers from mass balance fields, thinning rates, and a bed stress model. Journal of Climate 26(12), 4282-4303. doi: 10.1175/JCLI-D-12-00513.1.

Conway $\mathbf{H}$ and 5 others (2009) A low-frequency ice-penetrating radar system adapted for use from an airplane: test results from Bering and Malaspina glaciers, Alaska, USA. Annals of Glaciology 50(51), 93-97. doi: 10.3189/ 172756409789097487.

Dowdeswell JA and Evans S (2004) Investigations of the form and flow of ice sheets and glaciers using radio-echo sounding. Reports on Progress in Physics 67(10), 1821-1861. doi: 10.1088/0034-4885/67/10/R03.

Efron B (1979) Bootstrap methods: another look at the Jackknife. The Annals of Statistics, 1-26. doi: 10.1214/aos/1176344552.

Ehrbar D, Schmocker L, Vetsch DF and Boes RM (2018) Hydropower potential in the periglacial environment of Switzerland under climate change. Sustainability 10(8), 2794. doi: 10.3390/su10082794.

Farinotti D, Huss M, Bauder A and Funk M (2009a) An estimate of the glacier ice volume in the Swiss Alps. Global and Planetary Change 68(3), 225-231. doi: 10.1016/j.gloplacha.2009.05.004.

Farinotti D, Huss M, Bauder A, Funk M and Truffer M (2009b) A method to estimate the ice volume and ice-thickness distribution of alpine glaciers. Journal of Glaciology 55(191), 422-430. doi: 10.3189/002214309788816759.

Farinotti D and 36 others (2017) How accurate are estimates of glacier ice thickness? Results from ITMIX, the Ice Thickness Models Intercomparison eXperiment. The Cryosphere 11(2), 949-970. doi: 10.5194/tc-11-949-2017.

Farinotti D, Round V, Huss M, Compagno L and Zekollari H (2019) Large hydropower and water-storage potential in future glacier-free basins. Nature 575(7782), 341-344. doi: 10.1038/s41586-019-1740-z.

Farinotti D and 20 others (2021) Results from the Ice Thickness Models Intercomparison eXperiment phase 2 (ITMIX2)-dataset. Frontiers in Earth Science 8(484), 1-21. doi: 10.3389/feart.2020.571923.

Feiger N, Huss M, Leinss S, Sold L and Farinotti D (2018) The bedrock topography of Gries-and Findelengletscher. Geographica Helvetica 73(1), 1-9. doi: 10.5194/gh-73-1-2018.

Finger D, Heinrich G, Gobiet A and Bauder A (2012) Projections of future water resources and their uncertainty in a glacierized catchment in the Swiss Alps and the subsequent effects on hydropower production during the 21 st century. Water Resources Research 48(2), 1-20. doi: 10.1029/2011WR010733.

Fink AH and 5 others (2004) The 2003 European summer heatwaves and drought-synoptic diagnosis and impacts. Weather 59(8), 209-216. doi: 10. 1256/wea.73.04.

Fischer A, Olefs M and Abermann J (2011) Glaciers, snow and ski tourism in Austria's changing climate. Annals of Glaciology 52(58), 89-96. doi: 10. 3189/172756411797252338.

Fischer M and 5 others (2013) Estimation of basal shear stresses from now ice-free LIA glacier forefields in the Swiss Alps. EGUGA EGU2013-150.

Fischer M, Huss M, Barboux C and Hoelzle M (2014) The new Swiss Glacier Inventory SGI2010: relevance of using high-resolution source data in areas dominated by very small glaciers. Arctic, Antarctic, and Alpine Research 46(4), 933-945. doi: 10.1657/1938-4246-46.4.933.
Fischer M, Huss M and Hölzle M (2015) Surface elevation and mass changes of all Swiss glaciers 1980-2010. The Cryosphere 9(2), 525-540. doi: 10.5194/ tc-9-525-2015.

Frey H, Haeberli W, Linsbauer A, Huggel C and Paul F (2010) A multi-level strategy for anticipating future glacier lake formation and associated hazard potentials. Natural Hazards and Earth System Sciences 10(2), 339-352.

Funk M, Gudmundsson GH and Hermann F (1994) Geometry of the glacier bed of the Unteraargletscher, Bernese Alps, Switzerland. Zeitschrift fuer Gletscherkunde und Glazialgeologie 30, 187-194.

Gabbi J, Farinotti D, Bauder A and Maurer H (2012) Ice volume distribution and implications on runoff projections in a glacierized catchment. Hydrology and Earth System Sciences 16(12), 4543-4556. doi: 10.5194/ hess-16-4543-2012.

Gacitúa $\mathbf{G}$ and 5 others (2015) $50 \mathrm{MHz}$ helicopter-borne radar data for determination of glacier thermal regime in the central Chilean Andes. Annals of Glaciology 56(70), 193-201. doi: 10.3189/2015AoG70A953.

Gärtner-Roer I and 5 others (2014) A database of worldwide glacier thickness observations. Global and Planetary Change 122, 330-344. doi: 10.1016/j. gloplacha.2014.09.003.

Gaudard L (2015) Pumped-storage project: a short to long term investment analysis including climate change. Renewable and Sustainable Energy Reviews 49, 91-99. doi: 10.1016/j.rser.2015.04.052.

Gaudard L, Gabbi J, Bauder A and Romerio F (2016) Long-term uncertainty of hydropower revenue due to climate change and electricity prices. Water Resources Management 30(4), 1325-1343. doi: 10.1007/s11269-015-1216-3.

Gharehchahi S and 6 others (2020) Glacier ice thickness estimation and future lake formation in Swiss Southwestern Alps? The upper Rhône catchment: a VOLTA application. Remote Sensing 12(20), 3443. doi: 10.3390/rs12203443.

GLAMOS (1881-2018) The Swiss Glaciers 1880-2016/17, Glaciological Reports no. 1-138, Yearbooks of the Cryospheric Commission of the Swiss Academy of Sciences (SCNAT). doi: 10.18752/glrep-series,Published since 1964 by VAW/ETH Zurich.

GLAMOS (2019) Swiss Glacier Mass Balance, release 2019. Glacier Monitoring Switzerland. doi: 10.18750/massbalance.2019.r2019.

GLAMOS (2020a) Swiss Glacier Ice Thickness, release 2020. Glacier Monitoring Switzerland. doi: 10.18750/icethickness.2020.r2020.

GLAMOS (2020b) Swiss Glacier Inventory 2016. Glacier Monitoring Switzerland. doi: 10.18750/inventory.sgi2016.r2020.

GlaThiDa Consortium W (2019) Glacier Thickness Database 3.0.1. World Glacier Monitoring Service. Zurich, Switzerland. doi: 10.5904/wgms-glathida-2019-03.

Glen JW (1955) The creep of polycrystalline ice. Proceedings of the Royal Society of London. Series A. Mathematical and Physical Sciences 228(1175), 519-538. doi: 10.1098/rspa.1955.0066.

Glen J and Paren J (1975) The electrical properties of snow and ice. Journal of Glaciology 15(73), 15-38. doi: 10.3189/S0022143000034249.

Grab $\mathbf{M}$ and 8 others (2018) Ice volume estimates of Swiss glaciers using helicopter-borne GPR: an example from the Glacier de la Plaine Morte. In 2018 17th International Conference on Ground Penetrating Radar (GPR), pp. 1-4. doi: 10.1109/ICGPR.2018.8441613.

Grab M and 15 others (2020) SwissGlacierThickness-R2020. ETH Research Collection. doi: 10.3929/ethz-b-000434697.

Gudmundsson GH (1994) Converging glacier flow - a case study: the Unteraarglacier, VAW Internal Report 131. Mitteilungen der Versuchsanstalt fur Wasserbau, Hydrologie und Glaziologie an der Eidgenossischen Technischen Hochschule Zurich.

Haeberli W and Hölzle M (1995) Application of inventory data for estimating characteristics of and regional climate-change effects on mountain glaciers: a pilot study with the European Alps. Annals of Glaciology 21, 206-212. doi: https://doi.org/10.3189/S0260305500015834.

Haeberli W (2005) Investigating glacier-permafrost relationships in highmountain areas: historical background, selected examples and research needs. Geological Society, London, Special Publications 242(1), 29-37. doi: 10.1144/GSL.SP.2005.242.01.03.

Haeberli W and 5 others (2016) New lakes in deglaciating high-mountain regions - opportunities and risks. Climatic Change 139(2), 201-214. doi: 10.1007/s10584-016-1771-5.

Haeberli W, Oerlemans J and Zemp M (2019) The future of alpine glaciers and beyond. Oxford Research Encyclopedia of Climate Science. New York: Oxford University Press. doi: 10.1093/acrefore/9780190228620.013.769.

Helfricht K, Huss M, Fischer A and Otto JC (2019) Calibrated ice thickness estimate for all glaciers in Austria. Frontiers in Earth Science 7, 68. doi: 10. 3389/feart.2019.00068. 
Hock R, Iken I and Wangler A (1999) Tracer experiments and borehole observations in the over-deepening of Aletschgletscher, Switzerland. Annals of Glaciology 28, 253-260. doi: https://doi.org/10.3189/ 172756499781821742 .

Huggel C, Haeberli W, Kääb A, Bieri D and Richardson S (2004) An assessment procedure for glacial hazards in the Swiss Alps. Canadian Geotechnical Journal 41(6), 1068-1083. doi: 10.1139/T04-053.

Huss M (2010) Mass balance of Pizolgletscher. Geographica Helvetica 65(2), 80-91. doi: 10.5169/seals-872744.

Huss M (2011) Present and future contribution of glacier storage change to runoff from macroscale drainage basins in Europe. Water Resources Research 47(7), 1-14. doi: 10.1029/2010WR010299.

Huss M (2013) Density assumptions for converting geodetic glacier volume change to mass change. The Cryosphere 7(3), 877-887. doi: 10.5194/ tc-7-877-2013

Huss M and Farinotti D (2012) Distributed ice thickness and volume of all glaciers around the globe. Journal of Geophysical Research: Earth Surface 117(F4), 1-10. doi: 10.1029/2012JF002523.

Huss M and Farinotti D (2014) A high-resolution bedrock map for the Antarctic Peninsula. The Cryosphere 8(4), 1261-1273. doi: 10.5194/ tc-8-1261-2014.

Huss M and Fischer M (2016) Sensitivity of very small glaciers in the Swiss Alps to future climate change. Frontiers in Earth Science 4, 34. doi: 10. 3389/feart.2016.00034.

Huss M, Farinotti D, Bauder A and Funk M (2008) Modelling runoff from highly glacierized alpine drainage basins in a changing climate. Hydrological Processes 22(19), 3888-3902. doi: 10.1002/hyp.7055.

Huss M, Zemp M, Joerg PC and Salzmann N (2014) High uncertainty in 21st century runoff projections from glacierized basins. Journal of Hydrology 510, 35-48. doi: 10.1016/j.jhydrol.2013.12.017.

Huybrechts O, Rybak O, Nemec J and Eisen O (2008) Towards a coupled three-dimensional glacier/mass balance model of the Morteratschgletscher, Engadin. In EGU General Assembly 2008, Vienna, Austria 18 April 2008.

Kennett M, Laumann T and Lund C (1993) Helicopter-borne radio-echo sounding of Svartisen, Norway. Annals of Glaciology 17, 23-26. doi: 10 . 3189/S0260305500012568.

Langhammer L, Rabenstein L, Bauder A and Maurer H (2017) Ground-penetrating radar antenna orientation effects on temperate mountain glaciers. Geophysics 82(3), H15-H24. doi: 10.1190/geo2016-0341.1.

Langhammer L and 6 others (2019b) Glacier bed surveying with helicopterborne dual-polarization ground-penetrating radar. Journal of Glaciology 65(249), 123-135. doi: 10.1017/jog.2018.99.

Langhammer L, Grab M, Bauder A and Maurer H (2019a) Glacier thickness estimations of alpine glaciers using data and modeling constraints. The Cryosphere 13(8), 2189-2202. doi: 10.5194/tc-13-2189-2019.

Lapazaran J, Otero J, Martín-Español A and Navarro F (2016) On the errors involved in ice-thickness estimates I: ground-penetrating radar measurement errors. Journal of Glaciology 62(236), 1008-1020. doi: 10.1017/jog.2016.93.

Linsbauer A, Paul F and Haeberli W (2012) Modeling glacier thickness distribution and bed topography over entire mountain ranges with GlabTop: application of a fast and robust approach. Journal of Geophysical Research: Earth Surface 117(F3), 1-17. doi: 10.1029/2011JF002313.

Linsbauer A and 6 others (subm.) The new Swiss Glacier Inventory SGI2016 from a topographic to a glaciological dataset. Frontiers in Earth Science.

Lüthi MP (1994) Stabilitaet steiler Gletscher. Eine Studie ueber den Einfluss moeglicher Klimaaenderungen. Untersuchungen am Beispiel eines Haengegletschers in der Westflanke des Eigers (Ph.D. thesis). Eidgenössische Technische Hochschule Zürich.

Lüthi MP (2000) Rheology of cold firn and dynamics of a polythermal ice stream (studies on Colle Gnifetti and Jakobshavns Isbrae). Mitteilungen der Versuchsanstalt fur Wasserbau, Hydrologie und Glaziologie an der Eidgenossischen Technischen Hochschule Zurich.

Magnin F, Haeberli W, Linsbauer A, Deline P and Ravanel L (2020) Estimating glacier-bed overdeepenings as possible sites of future lakes in the de-glaciating Mont Blanc massif (Western European Alps). Geomorphology 350(106913), 1-21. doi: 10.1016/j.geomorph.2019.106913.

Maisch M (2000) Die Gletscher der Schweizer Alpen: Gletscherhochstand 1850, aktuelle Vergletscherung, Gletscherschwund-Szenarien. Vdf, Hochschulverlag AG an der ETH.

Margrave GF and Lamoureux MP (2019) Numerical methods of exploration seismology: with algorithms in MATLAB ${ }^{\circ}$. Cambridge: Cambridge University Press. doi: 10.1017/9781316756041.
Merz K and 5 others (2015) Evaluation of ground-based and helicopter ground-penetrating radar data acquired across an Alpine rock glacier. Permafrost and Periglacial Processes 26(1), 13-27. doi: 10.1002/ ppp. 1836.

Milner AM, Brown LE and Hannah DM (2009) Hydroecological response of river systems to shrinking glaciers. Hydrological Processes: An International Journal 23(1), 62-77. doi: 10.1002/hyp.7197.

Moll A (2012) Tiefengletscher, Uri: Vergangenheits-und Gegenwartsanalyse, Eisradarmessungen zum Stand 2011 sowie Modellierungen einer zukünftigen möglichen Gletscherentwicklung (Ph.D. thesis). Geographisches Institut der Universität Zürich.

Morlighem M and 5 others (2011) A mass conservation approach for mapping glacier ice thickness. Geophysical Research Letters 38(L19503), 1-6. doi: $10.1029 / 2011$ GL048659.

Morlighem M and 37 others (2020) Deep glacial troughs and stabilizing ridges unveiled beneath the margins of the Antarctic ice sheet. Nature Geoscience 13(2), 132-137. doi: 10.1038/s41561-019-0510-8.

Muller F, Caflish T and Müller G (1976) Firn und Eis der Schweizer Alpen: gletscherinventar: Gletscherinventar Ergaenzungsband: Fotoliste. Eidgenössische technische Hochschule Zurich, geographisches institut.

Nicholson L and Benn DI (2006) Calculating ice melt beneath a debris layer using meteorological data. Journal of Glaciology 52(178), 463-470. doi: 10. 3189/172756506781828584

Paul F and Linsbauer A (2012) Modeling of glacier bed topography from glacier outlines, central branch lines, and a DEM. International Journal of Geographical Information Science 26(7), 1173-1190. doi: 10.1080/ 13658816.2011.627859.

Pelto BM, Maussion F, Menounos B, Radić V and Zeuner M (2020) Bias-corrected estimates of glacier thickness in the Columbia River Basin, Canada. Journal of Glaciology 66(260), 1051-1063. doi: 10.1017/jog.2020. 75.

Plewes LA and Hubbard B (2001) A review of the use of radio-echo sounding in glaciology. Progress in Physical Geography 25(2), 203-236. doi: 10.1177/ 030913330102500203.

Pritchard $\mathbf{H}$ and 5 others (2020) Towards Bedmap Himalayas: development of an airborne ice-sounding radar for glacier thickness surveys in HighMountain Asia. Annals of Glaciology 61(81), 35-45. doi: 10.1017/aog. 2020.29

Rabatel A, Sanchez O, Vincent C and Six D (2018) Estimation of glacier thickness from surface mass balance and ice flow velocities: a case study on Argentière Glacier, France. Frontiers in Earth Science 6, 112. doi: 10. 3389/feart.2018.00112.

Rignot E, Mouginot J, Larsen C, Gim Y and Kirchner D (2013) Low-frequency radar sounding of temperate ice masses in Southern Alaska. Geophysical Research Letters 40(20), 5399-5405. doi: 10.1002/2013GL057452.

Rolstad C, Haug T and Denby B (2009) Spatially integrated geodetic glacier mass balance and its uncertainty based on geostatistical analysis: application to the western Svartisen ice cap, Norway. Journal of Glaciology 55(192), 666-680. doi: 10.3189/002214309789470950.

Röthlisberger H and Funk M (1987) Schlussbericht ueber die Sondierungen 1986, Bericht No. 20.4. Mitteilungen der Versuchsanstalt fur Wasserbau, Hydrologie und Glaziologie an der Eidgenossischen Technischen Hochschule Zurich.

Rutishauser A, Maurer H and Bauder A (2016) Helicopter-borne groundpenetrating radar investigations on temperate alpine glaciers: a comparison of different systems and their abilities for bedrock mapping. Geophysics 81(1), WA119-WA129. doi: 10.1190/geo2015-0144.1.

Schaefli B, Manso P, Fischer M, Huss M and Farinotti D (2019) The role of glacier retreat for Swiss hydropower production. Renewable Energy 132, 615-627. doi: 10.1016/j.renene.2018.07.104.

Schwanghart W (2020) Experimental (Semi-)Variogram (www.mathworks. com/matlabcentral/fileexchange/20355-experimental-semi-variogram). MATLAB Central File Exchange. Retrieved September 15, 2020.

Schwanghart W and Kuhn NJ (2010) TopoToolbox: a set of Matlab functions for topographic analysis. Environmental Modelling \& Software 25(6), 770-781. doi: 10.1016/j.envsoft.2009.12.002.

Sharp M and 6 others (1993) Geometry, bed topography and drainage system structure of the Haut Glacier d'Arolla, Switzerland. Earth Surface Processes and Landforms 18(6), 557-571. doi: 10.1002/esp.3290180608.

Shugar DH and 9 others (2020) Rapid worldwide growth of glacial lakes since 1990. Nature Climate Change 10(10), 939-945. doi: 10.1038/s41558-0200855-4. 
Sugiyama S, Bauder A, Huss M, Riesen P and Funk M (2008) Triggering and drainage mechanisms of the 2004 glacier-dammed lake outburst in Gornergletscher, Switzerland. Journal of Geophysical Research: Earth Surface 113(F4). doi: 10.1029/2007JF000920.

Swisstopo (2010) Bundesamt für Landestopografie swisstopo-swissALTI3DDas hoch aufgelöste Terrainmodell der Schweiz.

Swisstopo (2019) Bundesamt für Landestopografie swisstopo-swissALTI3D, Ausgabebericht 2019.

Thyssen F and Ahmad M (1969) Ergebnisse seismischer Messungen auf dem Aletschgletscher. Polarforschung 39(1), 283-293.

Urbini S and 7 others (2017) Airborne Radio Echo Sounding (RES) measures on Alpine Glaciers to evaluate ice thickness and bedrock geometry: preliminary results from pilot tests performed in the Ortles Cevedale Group (Italian Alps). Annals of Geophysics 60(2), 0226. doi: 10.4401/ag-7122.

van Pelt W and 6 others (2013) An iterative inverse method to estimate basal topography and initialize ice flow models. The Cryosphere 7(3), 987-1006. doi: 10.5194/tc-7-987-2013.

VAW (1998) Mauvoisin - Gietrogletscher - Corbassieregletscher. Glaziologische Studie im Zusammenhang mit den Stauanlagen Mauvoisin, im Auftrag der Elektrizitaetsgesellschaft, report 55.05.7903, (M. Funk, unpublished, VAW ETH Zurich).

VAW (2010) Adduction de Zinal, Expertise mandatee par les Forces Motrices de la Gougra SA, vAW ETH Zurich.

VAW (2011) Gletscher- und Abflussentwicklung im Gebiet des Fieschergletschers 1900-2100, im Auftrag der Gommerkraftwerke AG, A. Bauder and D. Farinotti, unpublished, VAW ETH Zurich).

VAW (2012) Eisdickenverteilung der Gletscher im Aletschgebiet. Radarmessungen an den Gletschern Grosser Aletsch, Oberaletsch, Mittelaletsch, im Auftrag der Electra-Massa AG, Kanton Wallis, Dienststelle Wald und Landschaft, Sion, Kanton Wallis, Dienststelle Energie und Wasserkraft, Sion (A. Bauder and N. Zoller, unpublished, VAW ETH Zurich).

VAW (2014a) Eisvolumen der Gletscher im Mattmarkgebiet. Radarmessungen und Bestimmung des Eisvolumens sowie dessen zeitliche Entwicklung seit 1931, im Auftrag der Kraftwerke Mattmark AG, report No. 7902.52.60 (A. Bauder and I. Frei, unpublished, VAW ETH Zurich).

VAW (2014b) Radarmessungen auf dem Theodul- und Furgggletscher, im Auftrag der Grande Dixence SA, unpublished, VAW ETH Zurich.

VAW (2017a) Eisdickenmessungen auf dem Vadret dal Cambrena: Helikoptergestuetzte Radarmessungen (A. Bauder and M. Grab, unpublished, VAW and IfG, ETH Zurich).

VAW (2017b) Eisdickenverteilung und Gletscherbett-Topographie des Oberaletschgletschers: Helikoptergestuetzte Radarmessungen (A. Bauder and M. Grab, unpublished, VAW ETH Zurich).

VAW (2019) Ground-Penetrating Radar (GPR) investigations in the terminus area of Oberaletschgletscher (D. Farinotti, H.R. Maurer, P. Carlen, M. Grab, and G. Church, unpublished, VAW and IfG, ETH Zurich).

Waechter H and Röthlisberger H (1982) Internal report No. 55.22. Mitteilungen der Versuchsanstalt fur Wasserbau, Hydrologie und Glaziologie an der Eidgenossischen Technischen Hochschule Zurich.

Watts RD and England AW (1976) Radio-echo sounding of temperate glaciers: ice properties and sounder design criteria. Journal of Glaciology 17(75), 39-48.

Watts RD and Wright DL (1981) Systems for measuring thickness of temperate and polar ice from the ground or from the air. Journal of Glaciology 27(97), 459-469.

Weidmann Y, Gandor F and Artuso R (2018) Temporale Metadaten swissALTI3D. Geomatik Schweiz 2018(11), 306-310.

Weidmann Y, Bärtschi H, Zingg S and Schmassmann E (2019) Das Schweizerische Gletscherinventar als Produkt des swissTLM3D. Geomatik Schweiz 2019(5), 114-119.

Welty E and 12 others (2020) Worldwide version-controlled database of glacier thickness observations. Earth System Science Data 12(4), 3039-3055. doi: 10.5194/essd-12-3039-2020.

Werder MA, Huss M, Paul F, Dehecq A and Farinotti D (2020) A Bayesian ice thickness estimation model for large-scale applications. Journal of Glaciology 66(255), 137-152. doi: 10.1017/jog.2019.93.

Woodward J and Burke MJ (2007) Applications of ground-penetrating radar to glacial and frozen materials. Journal of Environmental \& Engineering Geophysics 12(1), 69-85. doi: 10.2113/JEEG12.1.69.

Wyer H (2008) Die Nutzung der Wasserkraft im Wallis. Rotten-Vlg.
Zekollari H, Huss M and Farinotti D (2019) Modelling the future evolution of glaciers in the European Alps under the EURO-CORDEX RCM ensemble. The Cryosphere 13(4), 1125-1146. doi: 10.5194/tc-13-1125-2019.

Zemp M and 38 others (2015) Historically unprecedented global glacier decline in the early 21st century. Journal of Glaciology 61(228), 745-762. doi: 10.3189/2015JoG15J017.

\section{APPENDIX A. Interpolation with GlaTE}

The way the model after Clarke and others (2013) was implemented in GlaTE requires a DEM and glacier outlines as input data, whereas an apparent mass balance was calculated following Farinotti and others (2009b). The subdivision of individual glaciers into flowsheds, as required by the method of Clarke and others (2013), was computed from the DEM with the Matlab-based TOPO-Toolbox (Schwanghart and Kuhn, 2010).

In a first step of GlaTE, the Clarke model, yielding ice thickness distributions $h_{\text {Clarke }}(x, y)$, was calibrated using all available GPR data at locations $\left(x_{\mathrm{gpr}}\right.$, $y_{\text {gpr }}$ ) such that

$$
\bar{h}_{\text {Clarke }}\left(x_{\mathrm{gpr}}, y_{\mathrm{gpr}}\right)=\alpha \bar{h}_{\mathrm{GPR}}\left(x_{\mathrm{gpr}}, y_{\mathrm{gpr}}\right),
$$

with $\alpha=1$, by adjusting the apparent mass-balance gradients for the accumulation and ablation areas, with a constant ratio of 1.8 between the two (Farinotti and others, 2009b). This means that in average, the ice thickness predicted from the model match with the ice thickness measured with GPR. The calibrated model was used for all glaciers without GPR data, whereas the spread of the glacier-specific $\alpha$ values observed from all glaciers with GPR data were considered in the uncertainty analysis (Appendix D).

For all glaciers with GPR data, we accounted for measured ice thicknesses in a systematic manner using the inversion scheme of GlaTE. For the current study, this inversion scheme was modified after Langhammer and others (2019a) and is of the form:

$$
\left(\begin{array}{c}
\lambda_{1} \mathbf{G} \\
\lambda_{2} \mathbf{L} \\
\lambda_{2} \mathbf{B}_{\mathrm{gb}} \\
\lambda_{3} \mathbf{B}_{0} \\
\lambda_{4} \mathbf{S}
\end{array}\right) h_{\text {glate }}=\left(\begin{array}{c}
\lambda_{1} h_{\mathrm{GPR}} \\
\lambda_{2} \nabla h_{\text {Clarke }} \\
\lambda_{2} \nabla h_{\text {bound }} \\
\lambda_{3} \\
\lambda_{4}
\end{array}\right),
$$

where $h_{\text {Clarke }}$ is a $1 \times m$ array containing the ice thickness of the Clarke model, which is on a regular grid of dimension $n_{x} \times n_{y}=m$, and $h_{\text {glate }}$ is a $1 \times m$ array containing the ice thickness after applying constraints to the Clarke model. These constraints are the GPR-ice thickness $h_{\mathrm{GPR}}$, zero ice thickness at the glacier boundary, and a smoothing constraint, which are assigned to the corresponding modeling cells via the operators $\mathbf{G}, \mathbf{B}_{0}$ and $\mathbf{S}$, respectively, as explained in detail in Langhammer and others (2019a). Additionally, a constraint for the glacier bed slope close to the glacier boundary was introduced. It consists of an estimate of the glacier bed elevation gradient in the vicinity of the glacier boundary, $\nabla h_{\text {bound }}$, which was obtained by extrapolating the elevation gradient of the surface elevation DEM adjacent to the glacier into the glacier area. It was applied to the glacier model via the difference operator $\mathbf{B}_{\mathrm{gb}}$, which is a sparse matrix of dimension $m \times m$ populated only for model cells which are $<4$ cell-widths away from the glacier boundary. Another modification in comparison with Langhammer and others (2019b) is that for debriscovered areas the apparent mass-balance gradients were reduced by $40 \%$ (e.g. Nicholson and Benn, 2006).

In Eqn (A.2), $\lambda_{1}, \lambda_{2}, \lambda_{3}$ and $\lambda_{4}$ are the weighting factors for the corresponding constraints. When inverting for $h_{\text {glate, }}$ the goal was to give maximum weights to the Clarke model and the smoothness constraint while still fitting the GPR data. This was achieved by setting $\lambda_{1}=\lambda_{3}=1$ and defining values for $\lambda_{2}$ and $\lambda_{4}$ in an iterative manner. Starting with $\lambda_{2}=0.5$ and $\lambda_{4}=12$ we iteratively increased $\lambda_{2}$ and decreased $\lambda_{4}$ as long as the ice thickness of the GlaTE model $h_{\text {glate }}$ matches a minimum of $95 \%$ of the ice thickness measured by GPR within the uncertainty interval $\left[h_{\mathrm{GPR}}-\Delta h_{\mathrm{GPR}}^{-}, h_{\mathrm{GPR}}+\Delta h_{\mathrm{GPR}}^{+}\right]$. This procedure was applied to all except for 12 glaciers, which required a glacier model weight of $\lambda_{2}=0.1$ in order to appropriately fit the GPR data. The grid size of the GlaTE model was defined depending on the size of the glacier and was 10,30 or $50 \mathrm{~m}$, and up-sampled to $10 \mathrm{~m}$ grid size before averaging with the ITVEO model. 


\section{APPENDIX B. Interpolation with ITVEO}

The basic ice thickness model behind ITVEO builds on the concepts of Farinotti and others (2009b), but avoids the necessity of defining ice-flow lines and catchments by performing all computations on $10 \mathrm{~m}$ elevation bands sampled from the surface topography. The model takes into account variations in the valley shape and the basal shear stress along the glacier's longitudinal profile, as well as the variability in basal sliding along the glacier. Based on calibrated apparent mass-balance gradients, ice volume fluxes are estimated, and thickness is calculated by inverting the flow law for ice (Glen, 1955). Computed averages of elevation-band ice thickness are extrapolated to a regular grid by considering both local surface slope and distance from the glacier margin. We refer the reader to Huss and Farinotti (2012) for more details.

The ITVEO approach performs an optimization of computed ice thickness distribution on all individual point thickness observations at the scale of individual glaciers in a three-step procedure including (i) model optimization, (ii) spatial bias correction of modeled thickness and (iii) spatial interpolation based on measured point data and bias-corrected model results for un-surveyed regions. In a first step, the apparent mass-balance gradient (Huss and Farinotti, 2012) is calibrated to minimize the average misfit of computed thickness with the available observations. The apparent mass balance is computed as in Huss and Farinotti (2012) with two linear elevation gradients for the ablation and the accumulation area (with a fixed ratio of 1.8) prescribing a balanced mass budget of the entire glacier. In addition, negative apparen mass balance over debris-covered areas has been reduced by $40 \%$ to account for lower melt rates in these regions (e.g. Nicholson and Benn, 2006) Second, relative differences of modeled and measured point ice thicknesses were averaged using an inverse-distance weighting scheme in a radius of 50-500 $\mathrm{m}$ (depending on glacier size) for every gridcell and results were then spatially interpolated. After smoothing this relative spatial ice thickness correction field is superimposed on the computed ice thickness distribution, resulting in a bias-corrected model-based ice thickness distribution Although this result is corrected for errors in the model at the intermediate scale, it will not perfectly match GPR thickness on the profile. In a final and third step, the thickness distribution was thus spatially interpolated based on (1) all available thickness observations, (2) the model results adjusted in steps (i) and (ii), buffered in a distance of between 20 and $200 \mathrm{~m}$ (depending on glacier size) around the direct observations and (3) the condition of zero thickness on the glacier margin. This approach yields an agreement of the final ice thickness distribution at the point observations and relies on computed thickness, optimally adjusted to the measurements, in regions of the glacier without data. The ITVEO approach was used to evaluate thickness distribution for all 235 (recordings until 2019) glaciers with direct observations. For glaciers, without point thickness data (19\% of the overall glacier area in Switzerland) average parameters of the apparent mass-balance gradient for the respective glacier size class originating from step (i) were taken to run the ice thickness model.

\section{APPENDIX C. Components of point-specific ice thickness uncertainty}

Components considered when estimating point-specific ice thickness uncertainties from Eqn (3) are the interpolation uncertainty $u_{\text {int }}^{ \pm}(x, y)$, the GPR measurements uncertainty $u_{\mathrm{gpr}}^{ \pm}(x, y)$ and the surface elevation uncertainty $u_{\text {surf }}^{ \pm}(x, y)$.

For estimating $u_{\text {int }}^{ \pm}(x, y)$, a similar experiment is performed as the one presented by Farinotti and others (2021), which is a form of the bootstrap technique (Efron, 1979). The model-based ice thickness interpolation is repeated 30 times with GlaTE and ITVEO based on randomly selected subsets (20, 50 and $80 \%, 10$ times each) of the total GPR data. The deviations between modeled and measured ice thickness at locations of skipped data were then analyzed with respect to the distance $d$ to the closest retained point with measured ice thickness. In contrast to Farinotti and others (2021), points at the glacier boundary, where ice thickness is known to be zero, are also regarded as points with known ice thickness. Model misfits $\Delta h$ are defined as deviations of the modeled ice thickness from the GPR-ice thickness plus/minus the GPR-measurement uncertainty, and normalized by the modeled mean ice thickness of the corresponding glacier, $\bar{h}_{i}$. The distribution of the ice thickness deviations is shown in Figure S12 (Supplementary material) for 50-m distance intervals. For better visibility, zero-misfit values are clipped. They are strongly predominating because any fit within the GPR-uncertainty is regarded as a zero misfit.

For each distance interval, the mean and $2 \sigma$-confidence interval of the model misfit distribution was computed (red symbols in Supplementary Fig. S12). For distances up to around $500 \mathrm{~m}$, the dataset of model misfits is densely populated and we find a steady increase of the ice thickness deviation with increasing distance. To transfer this misfit to modeling cells without GPR data, a linear regression is fitted through the $2 \sigma$-confidence intervals for the distance ranges from 50 to $500 \mathrm{~m}$ and we find

$$
u_{\text {int }}^{+}(x, y)=\left(-\frac{27}{100}-\frac{0.077}{100} d(x, y)\right) \bar{h}_{i}
$$

and

$$
u_{\text {int }}^{-}(x, y)=\left(\frac{8}{100}+\frac{0.083}{100} d(x, y)\right) \bar{h}_{i}
$$

for misfits toward larger and smaller ice thickness, respectively. For glaciers without GPR data, Eqns (C.1) and (C.2) are applied using only the distance to the glacier boundary to specify $d$.

The impact of the GPR measurement uncertainty at each point on the glacier, $u_{\mathrm{gpr}}^{ \pm}(x, y)$, is estimated by repeating the ice thickness modeling while consistently using the maximum and minimum ice thickness with respect to the GPR uncertainty range. From model-based interpolation using minimum/ maximum observed thickness for all glaciers with GPR data, a minimummaximum range plus one standard deviation of the ice thickness calibration for glaciers without GPR data is calculated, yielding an estimate of $u_{\mathrm{gpr}}^{ \pm}(x, y)$ for those glaciers.

For the uncertainty in surface elevation, we assume $u_{\text {surf }}^{ \pm}(x, y)= \pm 10 \mathrm{~m}$. Parts of this estimate are due to the uncertainty of the DEM, which according to Swisstopo (2019) is $1-3 \mathrm{~m}$ for elevations above $2000 \mathrm{~m}$ a.s.l. Larger parts, however, are expected from defining the glacier surface elevation at the time of GPR data acquisition. For glaciers, for which the surface elevation was not properly logged during GPR data acquisition, the uncertainty in surface elevation is set to $u_{\text {surf }}^{ \pm}(x, y)= \pm 20 \mathrm{~m}$.

\section{APPENDIX D. Components of the ice volume uncertainty}

Components considered when estimating ice volume uncertainties from Eqns (4) and (5) are the interpolation uncertainties $\bar{u}_{\text {int }}$, GPR measurement uncertainties $\bar{u}_{\text {gpr }}$, glacier area uncertainties $\bar{u}_{\text {area }}$ and surface elevation uncertainties $\bar{u}_{\text {surf }}$. In contrast to the point-specific uncertainties in ice thickness, they have to be expressed as volumetric uncertainties under consideration of potential spatial correlations.

The point-specific interpolation uncertainty $u_{\text {int }}^{ \pm}(x, y)$ (Appendix C) is correlated with various degrees with the uncertainty of other cells, depending on inter-cell distance, GPR-data coverage and the lateral shape of the glacier. For propagating the spatially distributed ice thickness uncertainty to the volumetric interpolation uncertainty $\bar{u}_{\text {int, } i}$ of an entire glacier $i$, we therefore follow the approach introduced by Rolstad and others (2009), which takes this spatial correlation into account. From a variogram analysis after Schwanghart (2020), the correlation length $a_{i}$ is obtained for each glacier, which is a measure of the circular area $\pi a_{i}^{2}$, over which $u_{\text {int }}^{ \pm}(x, y)$ is typically correlated. For the example of Brunnifirn we find $a=170 \mathrm{~m}$. This is the radius of a circular area of the size of the black circle in Figures 6e and i, which roughly fits into the largest areas not covered with GPR data or into sidebranches of the glacier. From the correlation length and the standard deviation of $u_{\mathrm{int}, i}^{ \pm}(x, y)$, the volumetric interpolation uncertainty is computed from (after Rolstad and others, 2009)

$$
\bar{u}_{\text {int }, i}=L^{2} n \sigma_{\text {int }, i} \sqrt{\frac{1}{5} \frac{\pi a_{i}^{2}}{L^{2} n}},
$$

where $n$ is the number of gridcells inside the glacier outline, $L$ is the grid resolution and $\sigma_{\mathrm{int}, i}$ is the standard deviation of $u_{\mathrm{int}, i}^{ \pm}(x, y)$ over the entire glacier. In cases where the variogram analysis yields correlation lengths of similar dimension to glacier size, as sometimes occurring for very small glaciers, $u_{\text {int }}^{ \pm}(x, y)$ has to be expected to be strongly correlated across the entire glacier. In this case, we compute $\bar{u}_{\text {int }, i}=\sum_{k=1}^{p} u_{\text {mod }, k}^{ \pm}(x, y)$, where $p$ is the number of 
cells. For cells of different glaciers, no correlation is assumed and the volumetric interpolation uncertainty of all $m$ glaciers is computed from

$$
\bar{u}_{\mathrm{int}}=\sqrt{\sum_{i=1}^{m}\left(\bar{u}_{\mathrm{int}, i}\right)^{2}} .
$$

Volumetric uncertainties due to GPR errors are treated separately for glaciers with (subscript ' $w /$ ') and without (subscript 'w/o') GPR data, with $\bar{u}_{\mathrm{gpr}}^{2}=\bar{u}_{\mathrm{w} / \mathrm{gpr}}^{2}+\bar{u}_{\mathrm{w} / \mathrm{ogpr}}^{2}$. For obtaining $\bar{u}_{\mathrm{w} / \mathrm{gpr}, i}$, ensemble modeling is performed, assuming the GPR-uncertainty to be correlated only within specific GPR-profiles. Therefore, the ice thickness modeling of all $m$ glaciers is repeated 10 times, while the GPR-ice thickness is varied within the interval $\left[-c \Delta h_{\mathrm{GPR}}^{-}, c \Delta h_{\mathrm{GPR}}^{+}\right]$with $c$ being randomly chosen from a uniform distribution within the interval $[0,1]$ for each GPR-profile. For each realization $j$ the ice volume $\tilde{V}_{i, j}$ is computed. The uncertainty for an individual glacier $i$ with ice volume $V_{i}$ is then given by the standard deviation of the volume differences:

$$
\bar{u}_{\mathrm{w} / \mathrm{gpr}, i}=\sqrt{\frac{\sum_{j=1}^{10}\left(\tilde{V}_{i, j}-V_{i}\right)^{2}}{10}} .
$$

Across different glaciers, $\bar{u}_{\mathrm{w} / \mathrm{gpr}, i}$ is assumed to be uncorrelated. Therefore, uncertainty of the overall ice volume in Switzerland with respect to interpolation errors is given by

$$
\bar{u}_{\mathrm{w} / \mathrm{gpr}}=\sqrt{\sum_{i=1}^{m}\left(\bar{u}_{\mathrm{w} / \mathrm{gpr}, i}\right)^{2}} .
$$

For glaciers without GPR data, the volumetric uncertainty is estimated from the ice volume difference resulting from calibration with minimum and maximum GPR-uncertainties plus one standard deviation of the corresponding $\alpha$-values observed from GlaTE modeling according to Eqn (A.1). For both models GlaTE and ITVEO, this leads to ice volume uncertainties of $\sim \pm 20 \%$, and from the GlaTE model, the standard deviation of $\alpha$ from all glaciers with GPR data is found to be $30 \%$. Therefore, we set $\bar{u}_{\mathrm{w} / \mathrm{ogpr}, i}=\Delta \alpha V_{i}$ with $\Delta \alpha=(0.2+0.3)$. The uncertainty of the summed ice volumes of all glaciers without GPR data, $V_{\mathrm{w} / \mathrm{o}}$ is defined as $\bar{u}_{\mathrm{w} / \mathrm{ogpr}}=\Delta \alpha V_{\mathrm{w} / \mathrm{o}}$.

The range of errors in the areal extent of the glaciers, given by the SGI2016, is expected to be in the order of $5 \%$. We observed a difference of this magnitude when comparing the SGI2016 with the glacier area given by Weidmann and others (2019). To express it as a volume uncertainty, the area-uncertainty is multiplied with an estimate in ice thickness of the corresponding area. This ice thickness is much smaller than the overall mean ice thickness $\bar{h}_{i}$, since the areas in question are observed (by comparing with Weidmann and others, $2019)$ to be at the glacier margins and inside narrow snow-filled gorges. Here, this thickness is set to $(1 / 10) \bar{h}_{i}$. Therefore, the uncertainty for individual glaciers $i$ with area $A_{i}$ is then estimated from $\bar{u}_{\text {area }, i}=0.05 A_{i}(1 / 10) \bar{h}_{i}$. It is potentially strongly correlated among all glaciers, for example by systematically missing glacier parts in the shadow of high rock cliffs with very poor visibility on orthoimages. Thus, for the overall Swiss-wide volume uncertainty we compute $\bar{u}_{\text {area }}=\sum_{i=1}^{m} \bar{u}_{\text {area }, i}$.

Errors of the DEM are expected to be partially averaged out, when averaging across larger areas. However, in case of spatial correlations, e.g. with slope and exposure, some systematic errors will still be inherent. An error $\mathrm{d} z=0.5 \mathrm{~m}$ is thus assumed which is substantially smaller than the pointspecific error of $10 \mathrm{~m}$ introduced above. For glaciers with erroneous surface elevation in the GPR dataset (see Section 2) we use $\mathrm{d} z=10 \mathrm{~m}$. The volumetric uncertainties with respect to surface elevation errors are then set to be $\bar{u}_{\text {surf }, i}=A_{i} \mathrm{~d} z_{i}$ and $\bar{u}_{\text {surf }}=\sum_{i=1}^{m} A_{i} \mathrm{~d} z_{i}$ 